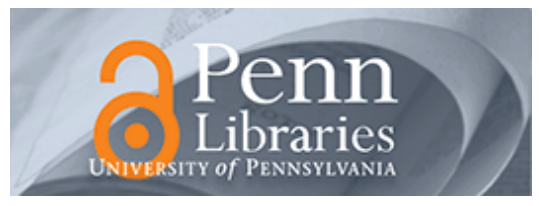

Studies in Visual Communication

Volume 5

Issue 2 Spring 1979

Article 2

1978

\title{
Paradigms Lost: A Peruvian Indian Surveys Spanish Colonial Society
}

Rolena Adorno

\section{Recommended Citation}

Adorno, R. (1979). Paradigms Lost: A Peruvian Indian Surveys Spanish Colonial Society. 5 (2), 78-96.

Retrieved from https://repository.upenn.edu/svc/vol5/iss2/2

This paper is posted at ScholarlyCommons. https://repository.upenn.edu/svc/vol5/iss2/2

For more information, please contact repository@pobox.upenn.edu. 
Paradigms Lost: A Peruvian Indian Surveys Spanish Colonial Society

This contents is available in Studies in Visual Communication: https://repository.upenn.edu/svc/vol5/iss2/2 


\section{PARADIGMS LOST: A PERUVIAN INDIAN SURVEYS SPANISH COLONIAL SOCIETY}

\section{ROLENA ADORNO}

\section{INTRODUCTION}

In the second decade of the seventeenth century, a self-proclaimed Peruvian cacique (ethnic lord) completed a treatise which is the richest, most comprehensive system of visual communication produced by a single source in the Andes. Felipe Guamán Poma de Ayala's Nueva corónica y buen gobierno (New Chronicle and Good Government) is the only known work by an Andean artist of the early colonial period that re-creates both native and foreign society in a literal, naturalistic manner. ${ }^{2}$ Faithfully depicting Andean culture and closely recording Western ways and Christian iconography, the 400 drawings of the 1200-page manuscript are an important potential source of ethnographic data about the Andean region. ${ }^{3}$ The work is considered the wellspring of "basic information about Andean institutions available nowhere else" (Murra 1970:6).

The Nueva coronica's documentary value has been demonstrated by its extensive use in fundamental studies of Andean economic organization (Murra 1978), prehistoric civilizations (Tello 1942), Inca law (Varallanos 1946), and the relatively new literature on the "vision of the vanquished" (Wachtel 1971).

The pictorial text has been studied for its symbolic content as a compendium of Andean thought (Ossio 1973:155-213; Wachtel 1973:165-228). Although partial studies on pictorial language in the Nueva corónica have been realized (Adorno in press; López-Baralt in press), Guamán Poma's visual system

Rolena Adorno teaches Latin American literature at Syracuse University. Her research interest is the artistic response to the collision of Old and New World cultures brought about by the Spanish Conquest. Her recent papers include "Racial Scorn and Critical Contempt," in Diacritics; "Guamán Poma's Nueva corónica y buen gobierno: An Andean View of the Peruvian Viceroyalty, 1565-1615," in Journal de la Société des Américanistes; and "On Pictorial Language and the Typology of Culture in a New World Chronicle," in Semiotica. With John V. Murra, she is preparing a critical edition of the Guamán Poma text. needs to be analyzed in its entirety and in its own right as a system of communication. The present discussion focuses on the structural composition and narrative content of the Nueva corónica drawings as they relate to symbolic Andean values.

Guamán Poma had just one principal reader in mind: King Philip III of Spain. ${ }^{4}$ According to the author, it was the king's duty to take the advice offered in this chronicle of historical and contemporary events and thereby remedy the grievances of the exploited Andean people. My contention is that the author-artist expresses his virulent criticism of the Spanish colonialists in a secret text-within-a-text. In the written narration, this coding takes the form of bitter anti-Spanish satire composed in the Quechua language. In the visual text, it consists of spatial compositions that conform to an Andean paradigm of positional values.

I would argue that the pictorial text contains two levels of meaning: The first is determined by the objects and events represented; the second, by the arrangement of those image-signs or icons in space. This latter mechanism, manipulated by the author or sender of the message, is not likely to be understood by the reader or receptor. Thus, two readings of the visual text are possible. The first is literal and innocent, and the second is privileged by the knowledge of the secondary system of signification or process by which meaning is generated. The following investigation is concerned with the second of these possible readings.

The position of icons in space and the related expressive properties of the pictorial field such as upper and lower, right and left, and directedness have specifically been analyzed as carriers of symbolic meaning (Schapiro 1969:229-234; Uspensky 1975:33-39 and 1976:219-246). It can be shown that there is a more complex source of secondary signification in the Nueva corónica. The hypothesis forwarded here is that a symbolic indigenous representation of the universe underlies the composition of all the drawings in the work that can be analyzed from the viewpoint of spatial contrasts and directional orientation; this group constitutes about two-thirds of the 399 drawings contained in the volume. The symbolic blueprint serves as the fundamental mechanism by which positive or negative value is assigned to the various classes of image-signs. ${ }^{5}$ Once the positional value of clusters of pictorial elements is determined, the substitution of one group for another can trace the process of paradigmatic transformation itself.

Narration in a pictorial text is accomplished through the transformation or internal transposition of fixed numbers of elements rather than by the lineal accumulation of new ones, as in verbal narrative (Lotman 1975:335). The pictorial elements to be discussed here are four basic classes of visual images, each of which is composed of two members in fundamental opposition: the gods/the human, the godly/the evil, the male/the female, and the master/ the servant. The patterns in which these images are 
elaborated are diagonal and horizontal arrangements or strings of pictorial signs. These will be coordinated with the values assigned to the categories of upper and lower, and right and left in the Andean scheme. One of the narrative aspects critical to this discussion is the replacement of one image class by another in a given compositional structure. A second concern is to see how a composition of a particular pattern and content is transformed into another design.

\section{ANDEAN SPATIAL DESIGN AND ITS TRANSFORMATION IN THE COLONIAL CONTEXT}

In Guamán Poma's chronicle, the object of transformational strategy is the fundamental design of Andean imperial organization: the quadripartite division of space organized around a center. The principle in question, illustrated in Figure 1, consists of two diagonal divisions of space. The first division divides upper and lower fields (with the upper position carrying the preferred value), while the second, an intersection of the first, simultaneously fixed the center of the design (the fifth sector) as well as the positions to right and left. On the horizontal plane, the central position represents maximum value and the position to the right of center carries a value superior to that of the left (Wachtel 1973:180-181). As stated earlier, the value attributes of the positions of Hanan, or upper and the right of center, and Hurin, or lower and the left of center, were recognized in Guamán Poma's own day. (See Note 5.)

Owing to the reversal of the visual field, which gives the same effect as a mirror image, from the viewpoint of the external observer the conceptual right will always be found on the pictorial left. Thus, the sectors in Figure 1 marked Chinchay Suyo (I) and Ande Suyo (III) are designated as upper and right (viewer's left), while Conde Suyo (IV) and Colla Suyo (II) represent the lower and left (viewer's right).

The conceptual model of Andean spatial distribution and value is reflected in Guamán Poma's mapa mundi, or map of the world (Figure 2), which organizes the modern colonial world in pre-Hispanic terms. The imperial capital of Cuzco, plus the arms of Castile and the crest of the Roman Catholic papacy, occupy the central portion of a symbolic universe constituted by the ancient realms of Chinchay Suyo (I), Colla Suyo (II), Ande Suyo (III), and Conde Suyo (IV). The order of priority among the four regions in Figure 2 is the same as that in Figure 1. From our vantage point, that priority of rank progresses from left to right, then top to bottom.

The mapping of preferential values in space according to the Andean paradigm is repeated in drawings that depict the foreign political structure and even its spiritual order. Castile, like Peru, is pictured as four domains arranged around a center, and the Christian concept of the City of Heaven is materialized as four fortresslike structures surrounding the

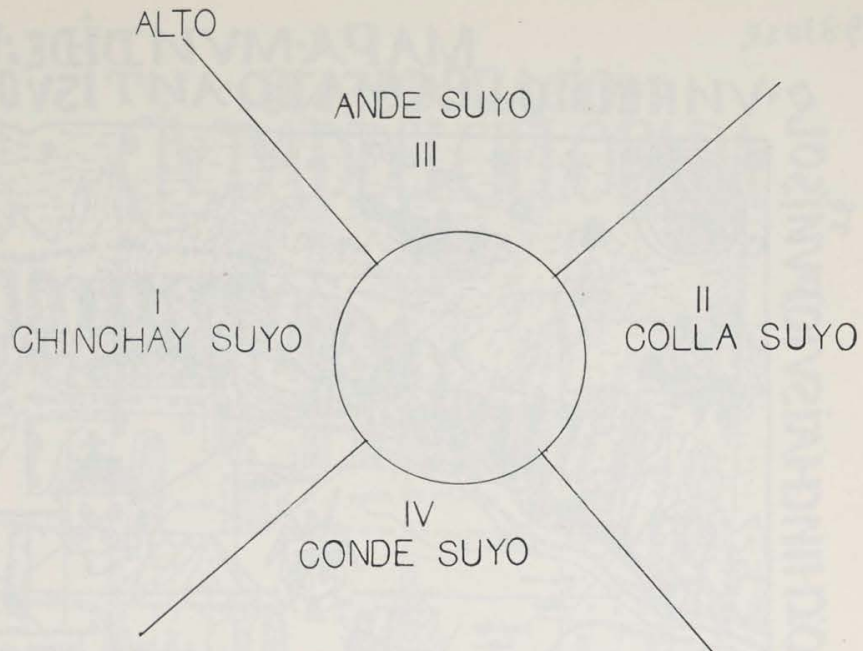

BAJO

Figure 1 -The symbolic Andean representation of the universe: the system of the four regions (Wachtel 1973:181).

Fountain of Eternal Life, in Figures 3 and 4 (Wachtel 1973:211-212). Since key foreign institutions are modeled according to autochthonous concepts, all the pictorial narrations should be examined to see if they can be explained as variations of the pattern. If the artist does in fact organize all the phenomena of real and hypothetical, historical and mythical experience according to that grid, the scale of values inherent in it will serve as a powerful tool to interpret the events visually recorded.

In addition to Figures 2, 3, and 4, there are only two other pictures in the entire work which present all or nearly all the features of the ancient design. These drawings are more subtle in their use of the abstract Andean structure than those discussed above. As such, their analysis serves as the introduction to the problems of positional value and textual interpretation under investigation here. One of these pictures records a historical event: the fateful encounter between Atagualpa Inca and Francisco Pizarro at Cajamarca, which changed forever the course of Andean history (Figure 5). The other is an imaginative reorganization of institutional powers: the author's decorative title page drawing of the relationship of the Catholic papacy and the Spanish crown to the Indies (Figure 6).

The Atagualpa/Pizarro picture is the middle moment of a number of kaleidoscopic transformations of which the mapa mundi (Figure 2) is the initial design and the title page a subsequent, intermediate reorganization. The final stage of transformation, implicit in the text, will be discussed later. As the mapa mundi stands for traditional political order revivified in colonial times, "Atagualpa in the City of Cajamarca" concretely represents the unwanted permutation of those values within the structural bounds of the traditional context. 


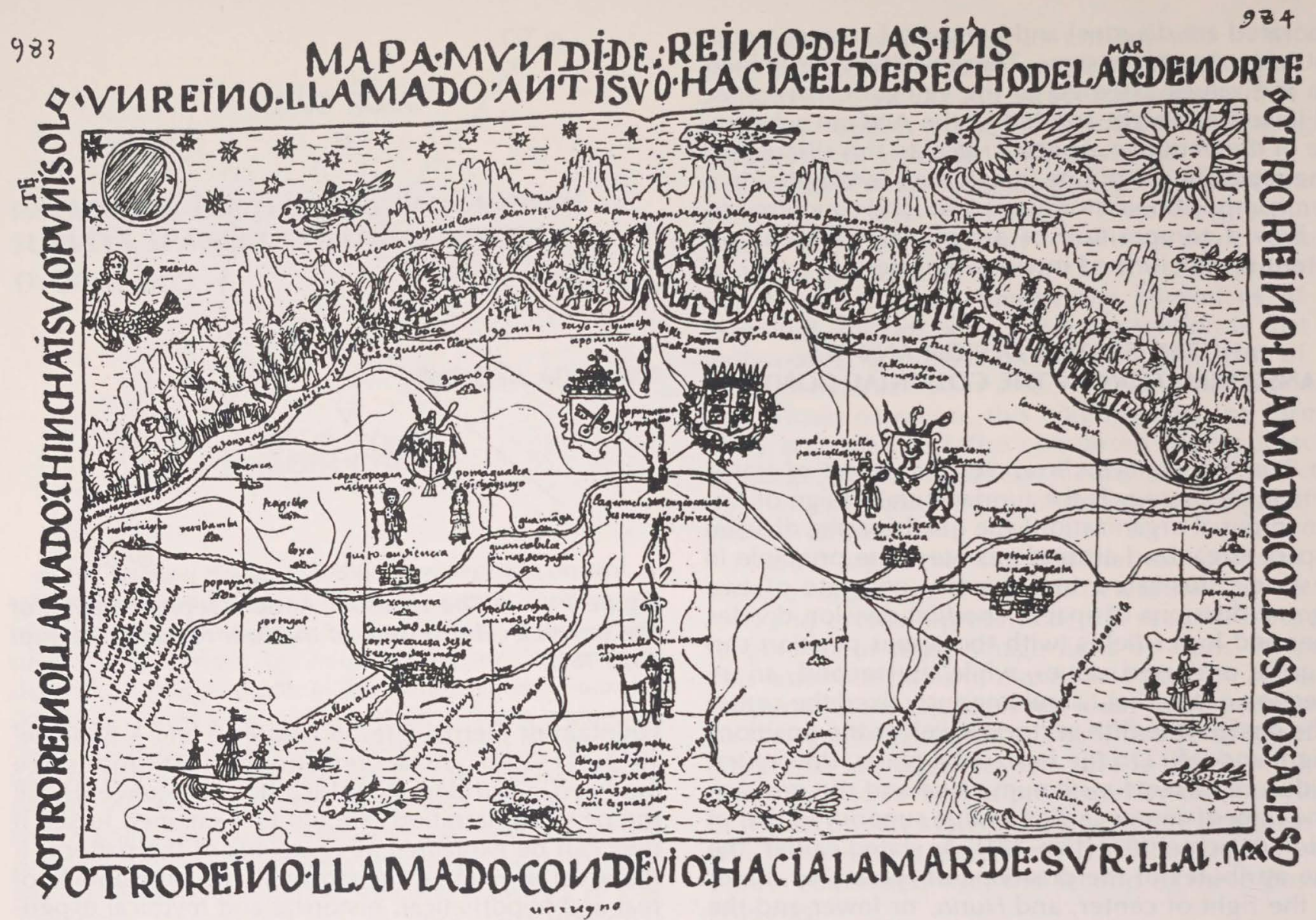

Figure 2 -The mapa mundi: The classical model of the Andean empire, consisting of Cuzco surrounded by the four subdivisions, framed in European style (Guamán Poma 1936:983-984).

Guamán Poma's frequent verbal complaint that the Spanish Conquest turned the Peruvian world upside-down is here rendered graphically by the reversal of the signs identifying the four subdivisions. "The Great Council of the Inca" places the four lords in their rightful positions, as identified by a system of headdress consistent throughout the text (Wachtel 1973:178; Figure 7). However, in the Cajamarca tableau the lords representing the more prestigious realms are reversed from their normal positions on the field and come to occupy the place of their inferiors; the latter have meanwhile taken the preferred positions to the right of the Inca (the viewer's left). Thus Guamán Poma creates a moment of upheaval, antithetical to the proper order. Nevertheless, the center and hub of the imperial regime are maintained by the Inca's illegitimate brother, the usurper Atagualpa. Because the framework has been altered, the central stability provided by Atagualpa is a tenuous one. Importantly, the alto/bajo (high/low) dichotomy of planes still separates the Inca sector from the Spanish conquistadores who have intruded into Andean space.

There is also an arrangement and gradation of value within the lower division of space, symbolically filled by four figures reminiscent of the four lordly posi- tions of the imperial kingdom of Tawantin Suyo. Owing to the differential values of right and left, Almagro, Pizarro, Fray Vicente, and Felipe the Indian interpreter can be ranked respectively in a descending order of value. According to the spatial signs, the position of the priest makes him more reprehensible than the conquering soldier-adventurers; the Indian liaison, a traitor to his race, occupies a place that categorizes him as the most despicable of all.

In sum, while this tableau ostensibly depicts a historical moment, it provides, at the same time, a silent essay on the subversion of the traditional order and the introduction of four new elements which will be the hurly-burly constituents of a new regime: the Spanish conquistador, his lieutenant, the Catholic priest, and the Indian who serves them. Thanks to the configuration of spatial signification, "Atagualpa in the City of Cajamarca" is the essential statement about a paradigm of order on the verge of being overturned. The center will be emptied and alien elements, symbolically numbered four, will replace the lords of Tawantin Suyo.

The other most complete re-creation of the original paradigm is the title page drawing (Figure 6). There is no Inca present here, and European figures take the place of nearly all the indigenous elements. The van- 


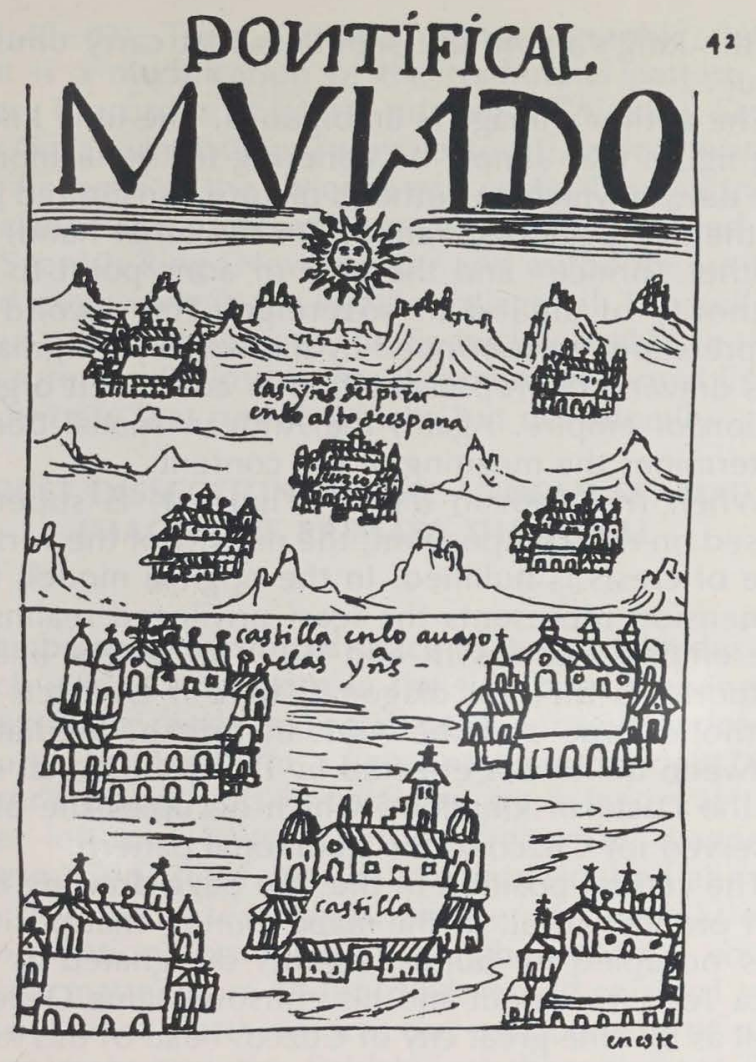

Figure 3 -The Peruvian Indies above Castile as four divisions around centers marked "Cuzco" and "Castile" respectively (1936:42).

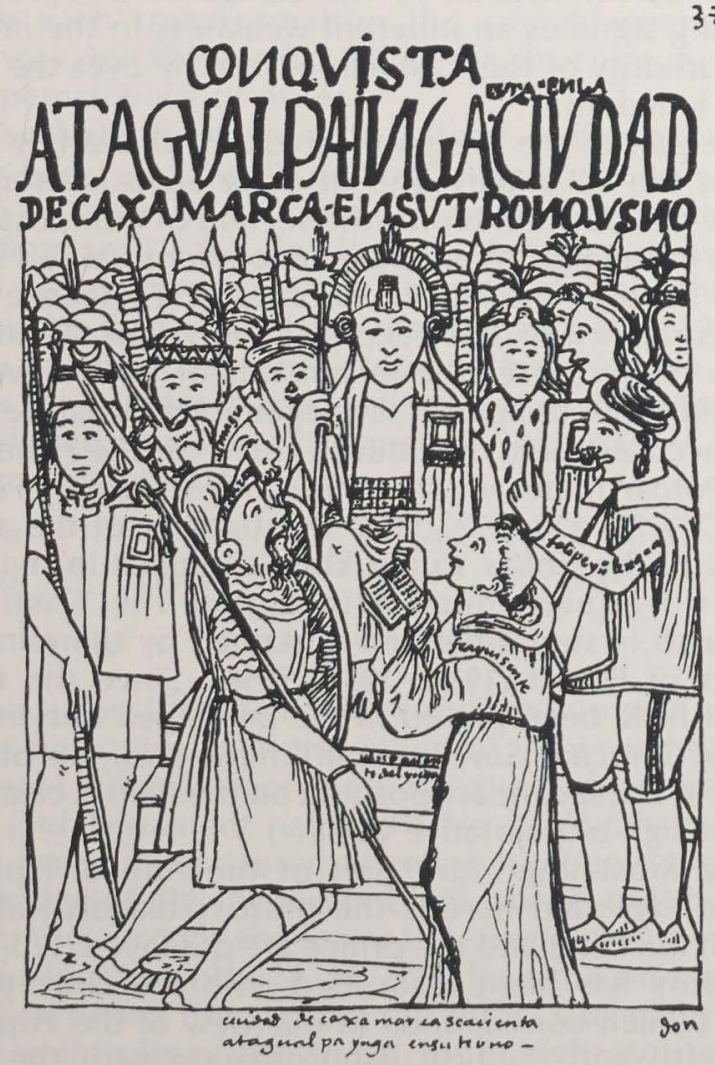

Figure 5 - Atagualpa in the City of Cajamarca" (1936:384).

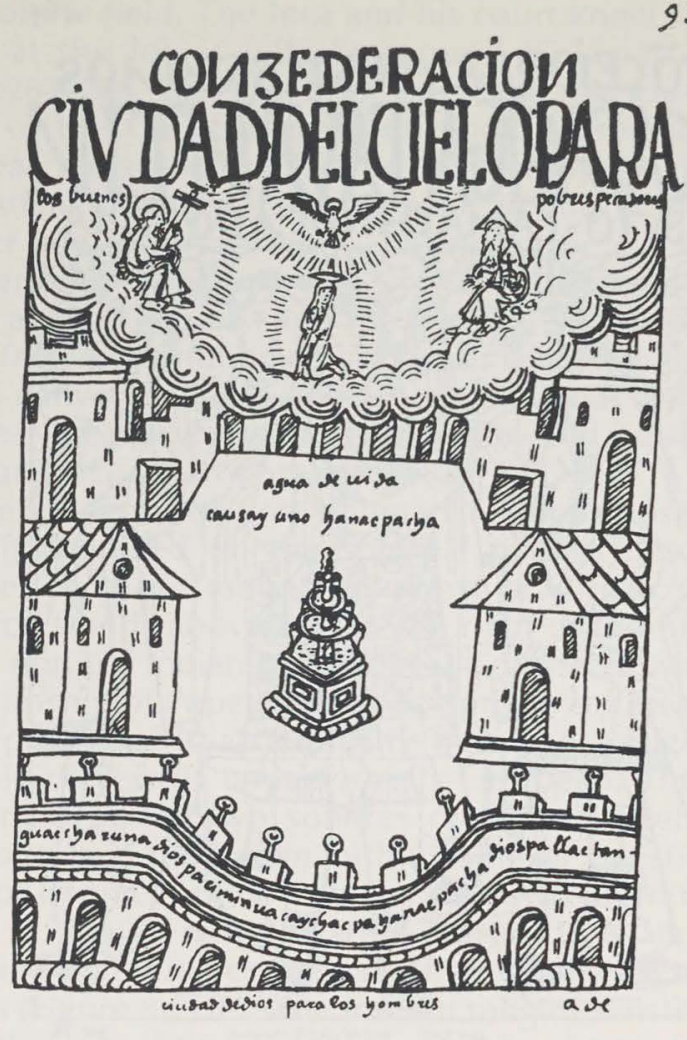

Figure 4 - "The City of Heaven" (1936:938).

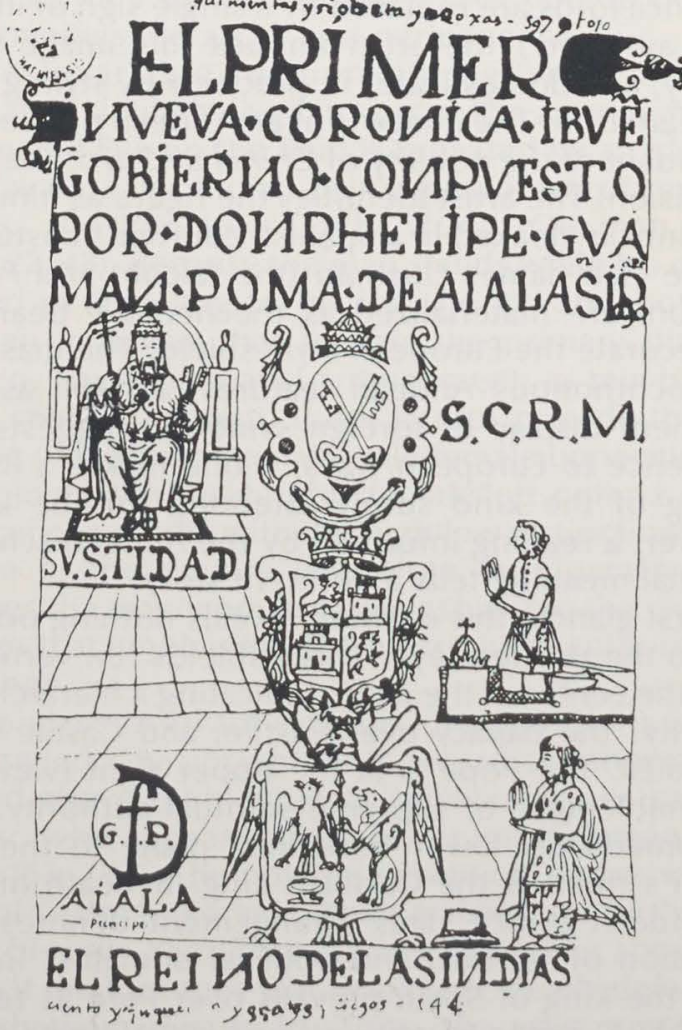

Figure 6 - "The First New Chronical and Good Government," title page (1936). 


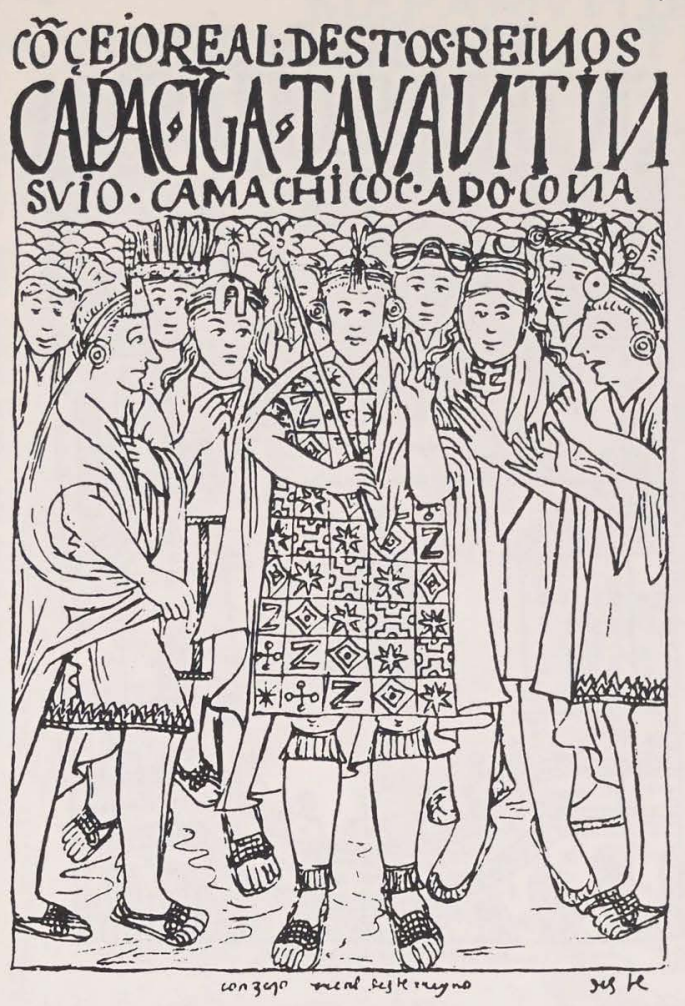

Figure 7-The Great Council of the Inca (1936:364).

ished Inca lords are replaced by a single sign of indigenous authority; the artist imbues this image with potency, and domesticates it, precisely by styling it in European form. The image is of an Andean prince and descendant of the nobility of Chinchay Suyo, the first subdivision. The artist identifies the figure as himself. The prince is cloaked in a Spanish courtier's costume, and the clan names Guamán (the falcon) and Poma (the lion) are materialized as the heraldic bearings that decorate the European-style shield. The masking of autochthonous Andean features, as well as the prominent display of foreign symbols, suggests acquiescence to European ways, if one makes a literal reading of the kind surely intended for the king. However, a reading informed by the Andean schema of spatial meaning tells a different story.

At first glance, this drawing reveals nothing odd or alien to the Western eye. Three shields run vertically down the center of the page, indicating a hierarchy of authority: the papacy over Castile, and Castile over the Indies. The Pope is at the upper right (viewer's left), emblematic of supreme spiritual authority. On the immediately lower horizontal plane to the left (viewer's right) is the Castilian king. Beneath him is the Andean prince. This arrangement denotes the separation of spiritual and political domains; in the latter, the king of Spain prevails over Peru as represented by Guamán Poma's self-portrait. Nevertheless, the presence of the author's picture and the position of the king's figure are signifiers that carry unusual value.

The author's image is ambiguous. The little kneeling figure may simply be adhering to the fashion of the day, in which an author's picture constituted part of the title page decoration. On the other hand, the epithet "prince" and the coat of arms point to the authority of an Indian sovereign. The second interpretation, corroborated by the written text, makes this drawing the representation of an explicit organization of empire. Again, the Andean spatial design determines the meaning of the content.

When the Andean model (Figure 1) is superimposed on this composition, the priority of the vertical line of crests is nullified. In the original model, that dimension represents the least privileged realms of the empire (sectors III and IV). The potent line of authority is the first diagonal; here it connects the Catholic Pope and the Andean prince. Mediation between the two is effected by the institutional sign of the Castilian kingdom, which occupies the place reserved for Cuzco in the traditional pattern.

The central position in the title page drawing is itself problematical. In the mapa mundi, that position was occupied by human figures designated as the Inca Topa Yupanqui and his consort Mama Ocllo as well as by "the great city of Cuzco, head of this kingdom of Peru" (Guamán Poma 1936:983-984; Figure 2). Even in the drawing that anticipates the Conquest, the usno (throne of the Inca) is occupied by the illegitimate Atagualpa (Figure 5). The absence of the king's personification in the center of the present drawing signifies an inherent weakness in the imperial authority of the Castilian monarchy over the Andean kingdom.

The part of the design reserved for the king's person is the secondary one of Colla Suyo (sector II). While this position is only the second of four possible ranks in the prototype, the connotations carried with Colla Suyo in the Nueva corónica text enhance the undesirability of the second subdivision. Guamán Poma characterizes the inhabitants of Colla Suyo as morally weak and physically degenerate by nature. He also accuses them of ruthless greed for the riches of the Potosí mines in their territory (Guamán Poma 1936:77-78, 170, 178, 336). The transfer of the attributes of the Collas to the king is implicit in the author's frequent declarations that the Castilian monarch is supported and sustained by the mineral riches of Potosí (1936: 1057, 1058). Since the king might have been placed in the privileged but empty slot of Chinchay Suyo (sector I in the grid), his placement in the secondary position on the field is clearly a secret sign of pejorative value.

The most important part of the Andean spatial image exploited here is the primary diagonal along which the Pope and the prince are deployed. Political authority has been associated with the conceptual right (which corresponds to our view of the Pope at the left), and political subordination with the left (in our view, the prince at lower right; Isbell 
1976:40-41). Thus, Guamán Poma's graphic statement is a modification of the traditional pattern of order. The order of lateral privilege, Chinchay Suyo over Colla Suyo (sector I over sector II), is deactivated here because of the absence of a sector I constituent to balance and oppose the sector II slot occupied by the Spanish king. Now, power and authority are located exclusively in the high/low diagonal. The nullification of the potency of the Spanish kingship in this structure results in the establishment of formal lines of authority that run diagonally but not laterally.

\section{FIRST DISSECTION OF THE ANDEAN SPATIAL IMAGE: THE PRIMARY DIAGONAL}

The primary division of space in the Andean design which was so important in the title page drawing is the exclusive model of organization for several dozen pictures. In all of them, a figure at the upper right (the viewer's upper left) is balanced by a figure at the lower left (our lower right) to create the diagonal pattern. Consistent with its use as described above, this line activates the principle of domination/ subordination. Examples of this phenomenon cover subject matter from all the represented spiritual and social orders. Furthermore, the replacement of one set of images on the field by another, such as the substitution of the Biblical Adam and Eve by the mythical Indian couple of the Vari Vira Cocha Runa, accomplishes the pictorial narration of chronologies from ancient mythical times to the colonial present. With each transformation the cast of characters changes, but the invariability of the structure signifies the permanence of order.

Essentially four types of cultural organization appear here, and the chronological progression within each of them will be discussed below. These configurations are (1) the theological-the relationships of man to his gods; (2) the religious-moral-the relationship of the godly to the humanly frail; (3) the sexual-patriarchal-the order of male/female relations; and (4) the political-the relationship of political domination and subjugation. The graphic summary is as indicated below:

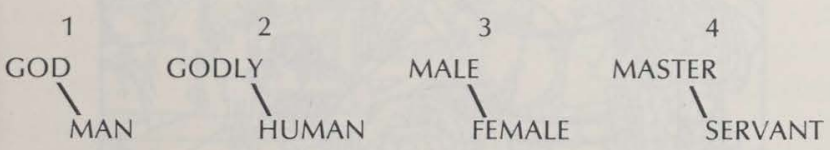

The Judeo-Christian deities and the sun god of the Incas both appear in the identical upper-right-hand segment in the category of theological subject matter. The Old Testament patriarchs Noah, Abraham, and King David are pictured kneeling in supplication to the image of divinity located high above and to their right; they occupy the lower left segment of the field (Guamán Poma 1936:24, 26, 28). The same structure is used to depict the gods of the Incas. Guaman Poma frequently places the Incas' idols high atop rocky peaks, thus positioning them in the upper right por- tion of the field. The Inca and his court kneel in worship at the lower left foreground (Guamán Poma $1936: 264,266,268,270,272)$. Later, the religious symbols of the Christian tradition come to replace the Andean idols, and the Inca is replaced by the devout Christian Indian worshiper, each in the respective upper and lower positions. Owing to the stability of the graphic structure, the symbols of Christianity, such as the Eucharist and the crucifix, supersede the Old Testament notion of godhead. Likewise, the Andean native, clad and coiffed in traditional style, becomes the modern successor of the Old Testament patriarch (Guamán Poma 1936:821, 823, 919).

The category of godly/human relationships is explicitly modeled on the spiritual pattern described above. In these tableux, a priest or officer of the Church stands above and to the right of the humble friar, nun, or Indian parishioner. Consistent with the relationship of Pope and Andean prince set up on the title page, spiritual authority over the indigenous people of Peru is unequivocally European. The separateness of the two spheres of Christian religious authority and the Indian faithful is never questioned, except in one curious instance. The two discrete cultural worlds merge in "Father Martín de Ayala," the drawing that initiates the use of the diagonal composition (Figure 8). Here the foreign religious institution and the autochthonous Andean race converge in a single symbol, for the priest is a mestizo, or halfcaste. Notwithstanding this exceptional case, the diagonal characterizes the relationship of Spanish religious patronage to the colonized Indians. The descending line defines position and counterposition and signifies hierarchy and permanence.

The invariable relationship between man and woman is similarly fixed in space. The arrangement of Adam and Eve on the field is repeated by an identical portrayal of the Indian man and woman of mythical times, the Vari Vira Cocha Runa (Guamán Poma $1936: 22,48)$. Because the man stands while his mate is seated or kneeling to his left, he towers above the woman in a way that repeats the primary diagonal design. For their spatial arrangement, as much as for their specific content, these figures provide the prototype of Guamán Poma's male/female opposition. By combining the male/right, female/left criteria of the Coricancha model with the high/low distinction of the image of the empire (see Note 4), Guamán Poma stylizes the man/woman relationship into the diagonal design that emphasizes the hierarchy of authority and privilege.

The master/servant category of oppositions is similarly styled. The ancient Incas are usually shown positioned above their subjects, adversaries, or captives in war, who appear to their lower left (Guamán Poma $1936: 153,159)$. The notable exception comes as a result of Guamán Poma's ethnic patriotism, for he portrays his own Yaro Bilca lineage struggling above and against the Inca foes that would eventually defeat and absorb them (Figure 9). Thus, the artist graphically demonstrates his claim that his own ancestors pre- 


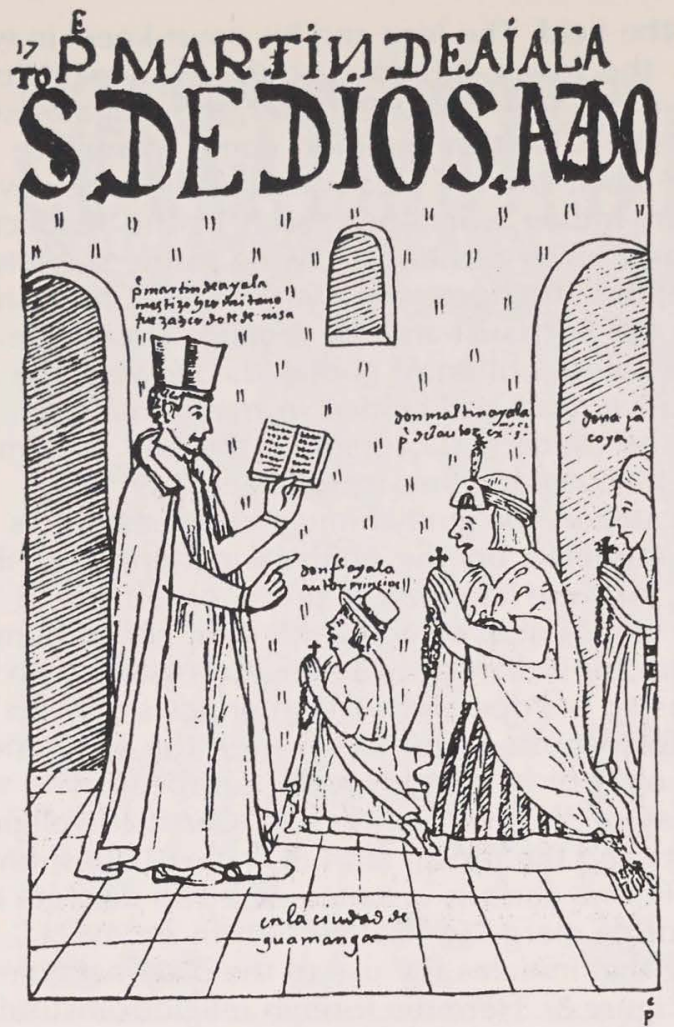

Figure 8 -Father Martin de Ayala with the author and his parents (1936:17).

968

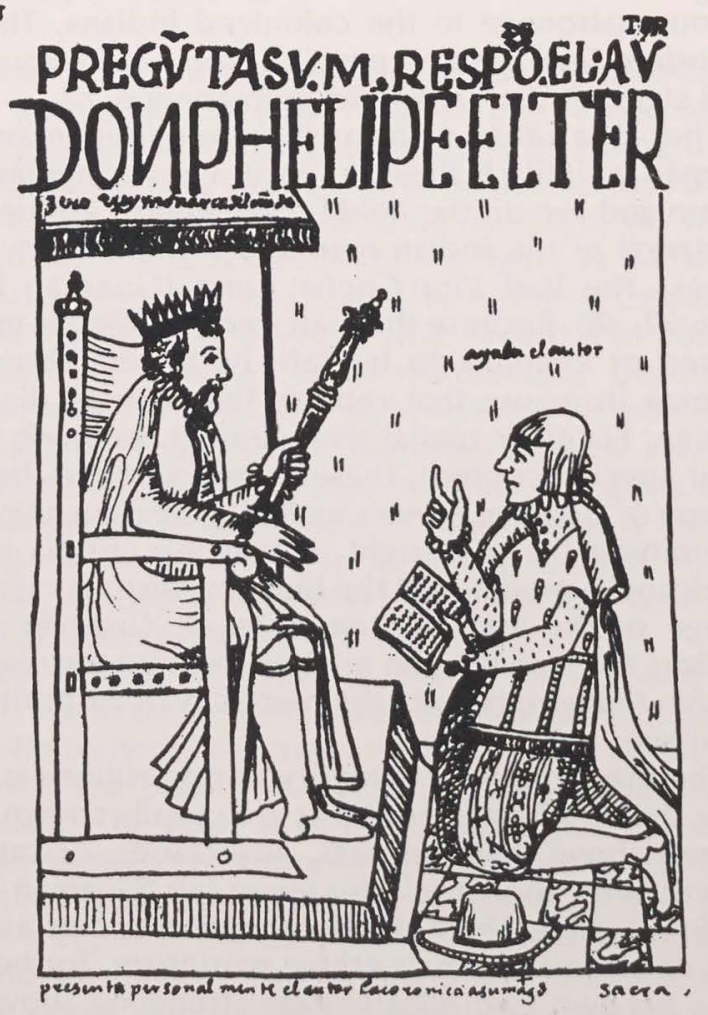

Figure $10 \quad$ - "The author personally presents his chronicle to His Majesty" (1936:961). iss

ELSETIMO CAPITÃ IVGA $M$ MATAC.

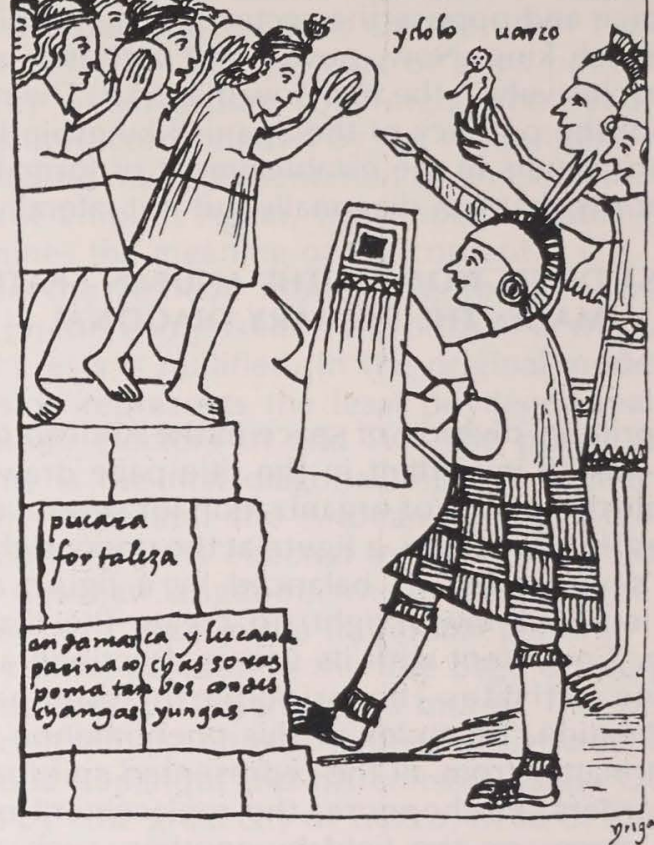

Figure 9 -The soldiers of Andamarcas-Lucanas-Soras defend themselves from the Inca conquerors (1936:155).

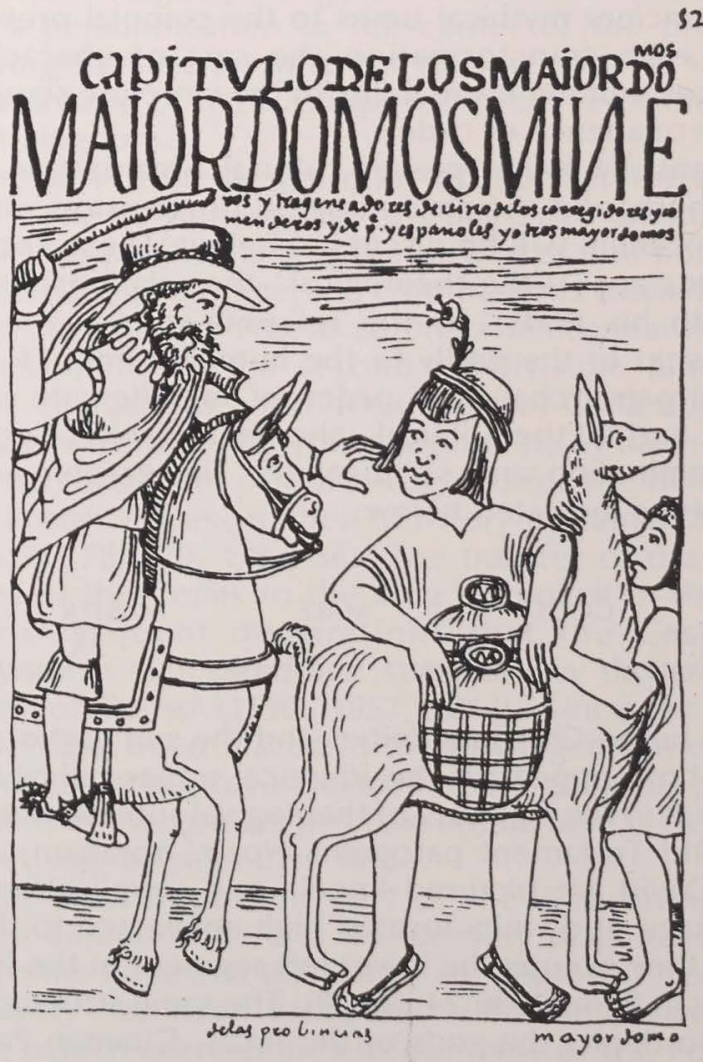

Figure $11-A$ majordomo abuses his servants (1936:524[bis]). 
dated the lowly Inca usurpers as the true Andean nobility. The diagonal line is also regularly used to represent the notion of political authority among the Europeans, as when the Emperor Charles V is pictured with one of his Spanish subjects (Guamán Poma 1936:417).

In this fourth category of political relationships, the problematic area is again the potential integration of the foreign colonists and the native Andeans into a single order. Whereas the Europeans come to exclusively occupy the position of religious authority in the second category, there are no pictures in the fourth to indicate that they usurp the role of political domination. In this case, that which is not represented becomes meaningful. Three pictures which potentially fill this lacuna bear specific comment.

The first of these is the only drawing in the work that interprets a direct Spanish/Andean political relationship on the primary diagonal axis; it bespeaks harmony, order, and good will (Figure 10). Reserved for a very special situation, the line that unites Spanish king and Peruvian vassal depicts King Philip III listening carefully to the advice given by Guaman Poma in his New Chronicle and Good Government. The central position of the book symbolically mediates the relationship between the two.

The other two drawings which place the Spaniards' figures in positions of power over the Andeans are structurally more complex than Figure 10. These utilize the sign of directional orientation to under- mine and negate the significance of the particular diagonal arrangements. While the construction of Figure 10 grants the authority of the foreign king over the Andean "prince," the structures of Figures 11 and 12 implicitly criticize the colonists' rule over the Peruvian natives and deny their right to hegemony. In one of these master/slave representations, a majordomo attacks an Indian servant (Figure 11). In the other, a Spanish encomendero directs Indian servants to carry him aloft in an Inca's litter (Figure 12). In both, the sign of directional orientation poses the Spanish figures facing leftward (rightward, from our vantage point). This contradicts the rightward (to us, leftward) orientation typically found in drawings of Inca times, which the author characterizes as an era of law and order (Figure 13; Guamán Poma 1936: 256, 289, 331, 333). The spatial sign of direction thus carries the positive and negative connotations of right and left. Through its use, the colonists are marked with the sign of disruption and disorder. Like the reversal of the emblems of the four subdivisions in the Atagualpa/Pizarro scene (Figure 5), the reversed directional orientation tells the ongoing story of a world turned upside-down.

The favored position of the upper right is filled with a modern Andean figure in very few compositions that depict the political situation in the colony. As the role of the ethnic lord is supplanted, the graphic position emblematic of vigorous authority is filled with Indian lackeys and black slaves who do the colonists'

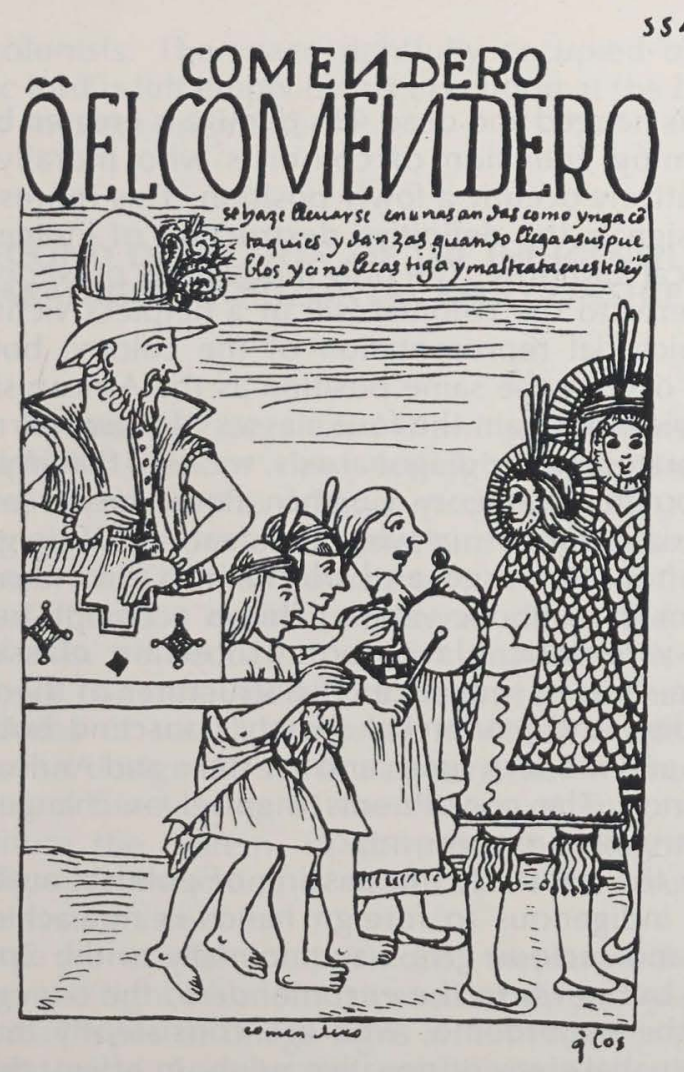

Figure 12 -An encomendero plays the Inca (1936:554).

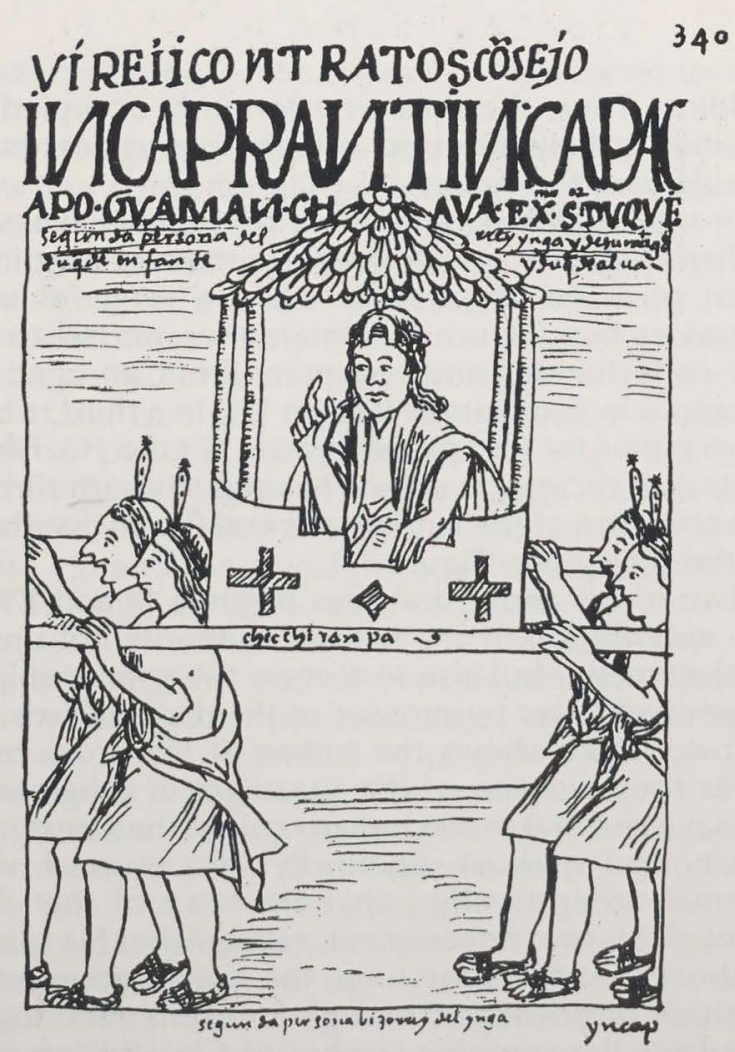

Figure 13 -The Inca's viceroy borne aloft (1936:340). 


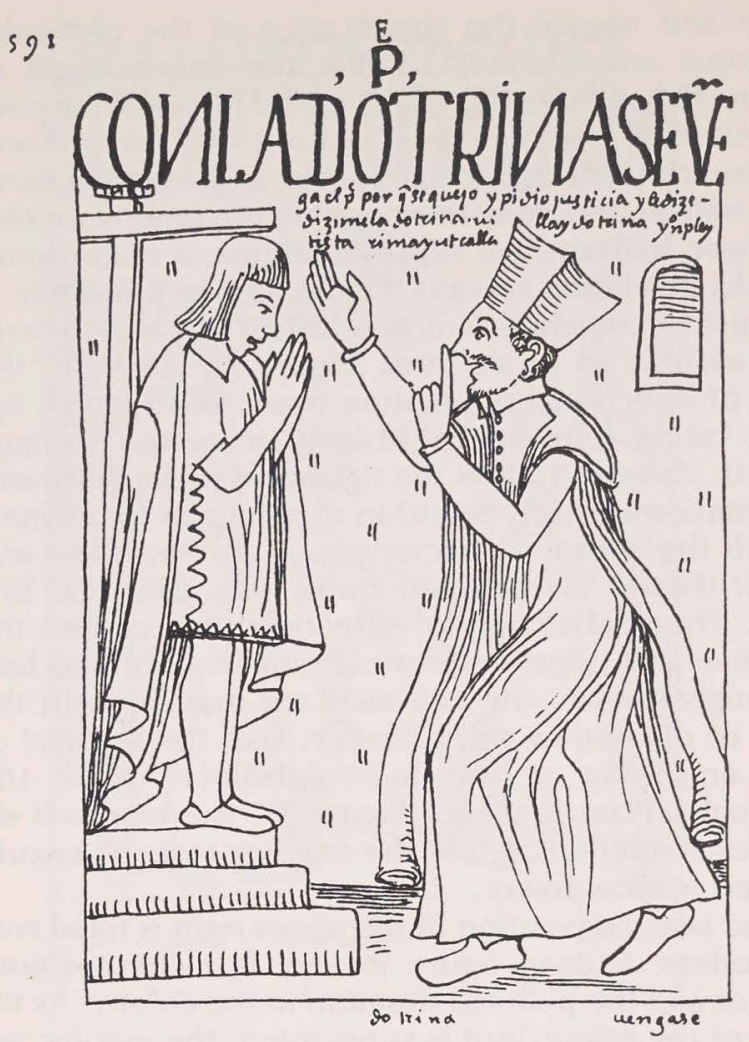

Figure $14-A$ priest silences an Indian's complaints by forcing him to recite doctrine (1936:591).

bidding. Thus, the Inca who formerly occupied this position is denied a direct autochthonous descendant to rule over the Andes.

In one of these renderings of colonial times, an Indian is shown as a defenseless martyr, standing in front of a life-size crucifix while a vengeful priest harrasses him (Figure 14). In another, an Indian tribute collector demands payment from an aged and destitute Indian woman (Figure 15). In a third, a black slave pimps for his Spanish master (Figure 16). Finally, an Indian cacique is shown hanged to death through the collusion of the land owner and the civil authority of the corregidor (Figure 17).

Two of the above drawings (Figures 14 and 17) use the nullification of the natives' authority not only as subject matter but also to reverse the relationships of upper and lower terminuses of the diagonal axis. The picture which shows the Indian at the cross represents the inversion of the paradigm of religious patronage and makes the Indian replace the priest in the position of spiritual superiority. This reversal of the normal order signifies that the man of the cloth, through his own debasement, relinquishes his spiritual authority. At the same time, the Indian occupies the position of privilege; through innocent suffering, he emulates the supreme symbol of Christian sacrifice. The only cacique to occupy the traditional place of

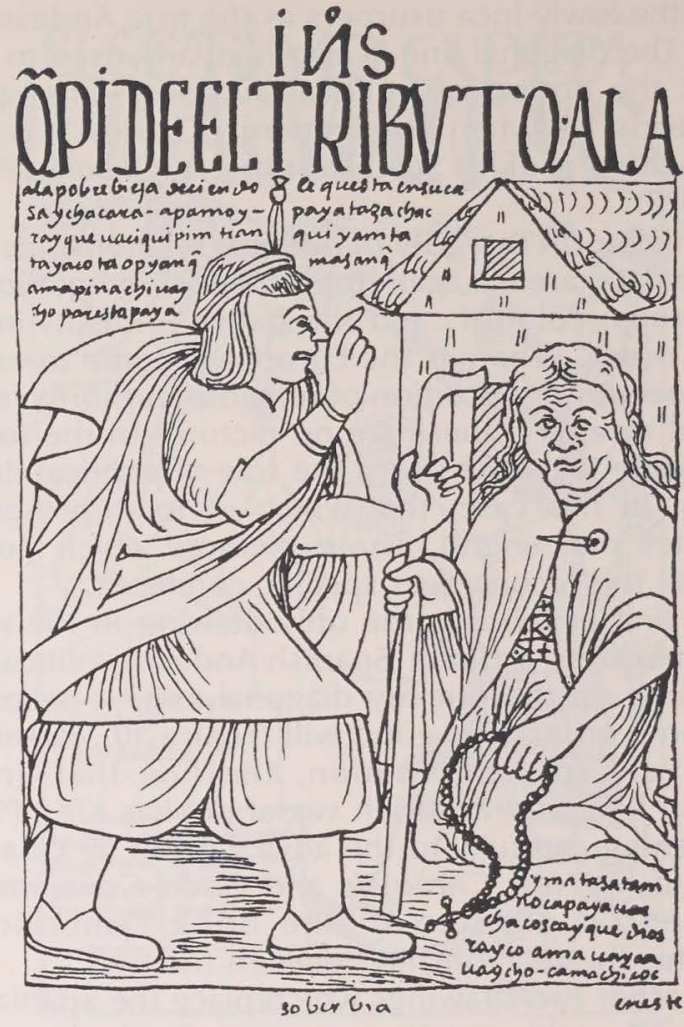

Figure $15-$ An Indian exacts tribute from the poor (1936:886). rank is hanged and dead. His demise is created by the scheming collusion of colonists who literally and figuratively occupy a lowly position. This representation signals the definitive destruction of indigenous political authority. The only indigenous presence is a panderer to the colonial will or a helpless victim. In the pictorial representation of the colony, both of them occupy the same position as the African slave.

Reviewing again the four classes of visual narration elaborated on the diagonal axis, we note that in all but the political category Guamán Poma has created a pictorial structure in which Andean and foreign experience converge and blend into a continuous stream of symbolic values. This is accomplished by the systematic placement of certain classes of image-signs in sequence. The structures of theology, morality, and patriarchal society transcend both ancient and modern times and Western and Andean experience. The constituents themselves change, but the structure remains intact.

On the contrary, the passing of political authority from indigenous to foreign hands is not achieved: Inca and cacique give way minimally to the Spanish king, but never to the encomendero, the corregidor, and the majordomo, who are consistently marked with spatial signs of negative value. In effect, the political prerogative as a constructive force is denied to 
$7 \circ 9$

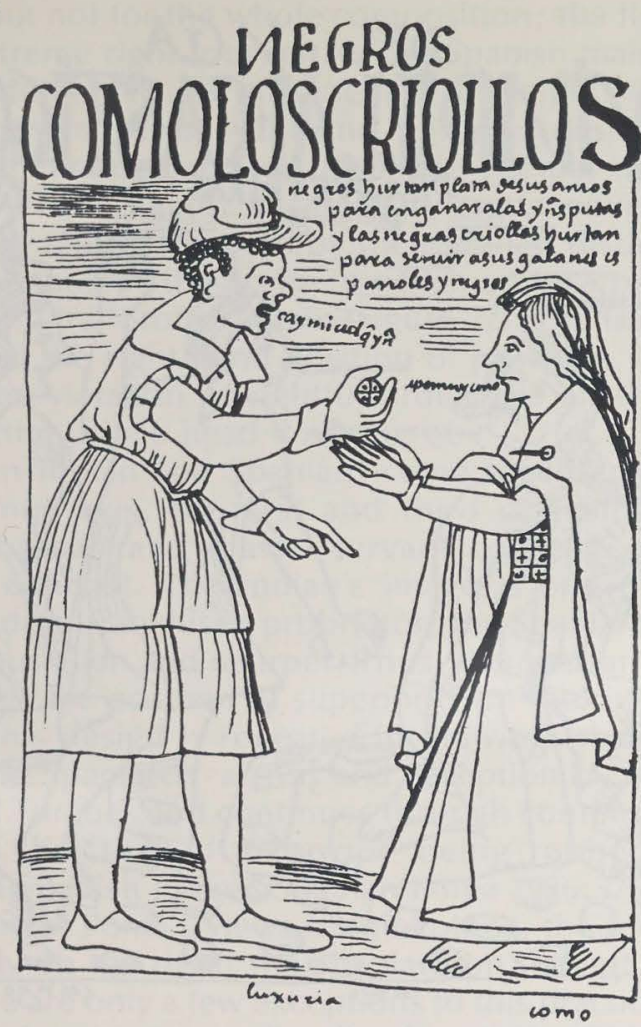

Figure 16 -A black slave pimps for his Spanish master (1936:709).

the colonists. The space rightfully occupied by the ethnic lord is left empty by his execution at the hands of his colonial enemies.

\section{SECOND DISSECTION OF THE INDIGENOUS PARADIGM: HORIZONTAL RELATIONSHIPS}

The horizontally organized drawings are based on the right/left (in our view, left/right) opposition of sectors I and II in the original model (Figure 1). This pattern is far more common than the diagonal arrangement in Guamán Poma's pictures. From the variety of thematic content rendered along the horizontal axis, we deduce that this composition is used to depict concrete social situations, rather than the formalities of social structure. In other words, the horizontal design is a syntactic phenomenon showing the actual functioning of the classes of images that constitute the system. In contrast, the diagonal is paradigmatic inasmuch as it articulates the structure of the system itself.

In the horizontal compositions, the favored position on the right (our left) is consistently occupied by particular types of image-signs whether from mythical, historical Andean, or contemporary colonial times. The persistent oppositions are: \$s 7

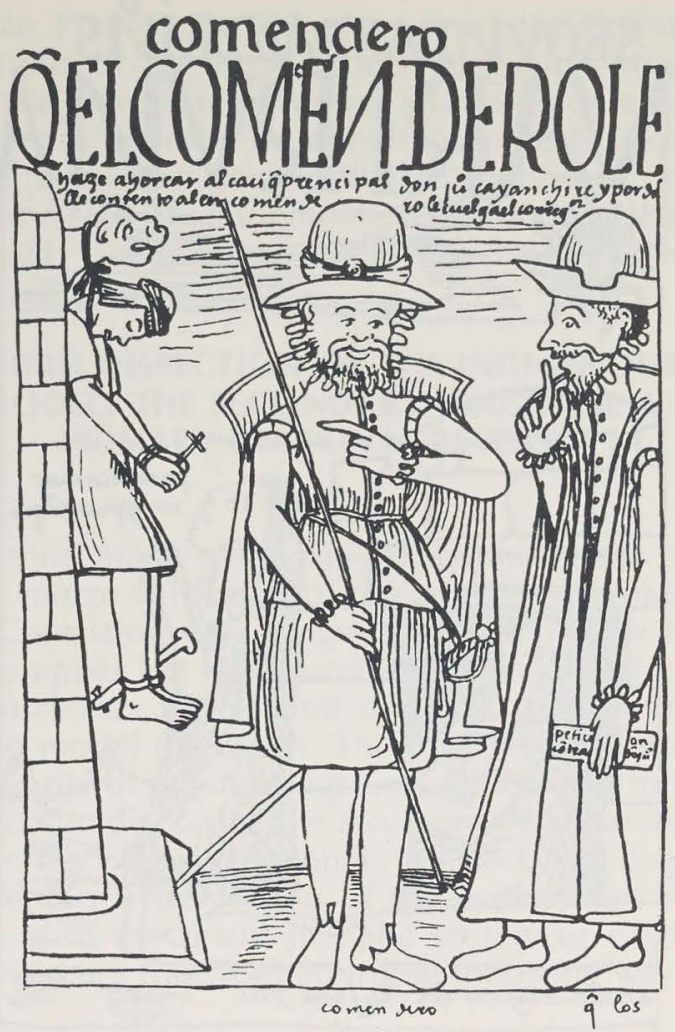

Figure $17-A$ cacique is hanged by the corregidor at the behest of the encomendero (1936:557).

GODLY/HUMAN

MALE/FEMALE

MASTER/SERVANT

The drawings that denote peaceable relationships follow the conventional position code given above. Those events or situations which are negatively interpreted reverse the normal ordering of image-signs.

Sex signs, for example, are reversed in the picture of ancient times that shows how incipient Andean civilization had only an imperfect and intuited knowledge of the true god (Figure 18). Whether religious, moral, or political, misguidedness is regularly indicated by the displacement of sex signs. Thus is rendered the punishment of sex crimes in Inca times (Figure 19) and the staging of pagan festivals (Figure $20)$. The same device is used to portray the colonial corruption of Indian women by the Spaniards, as when a corregidor and his lieutenant examine the nakedness of an Indian maiden by candlelight (Guamán Poma 1936:503). The perversion of the proper social order is the chief message conveyed by such pictures. Young Indian girls are shown being given to conquistadores and encomenderos (Guamán Poma $1936: 379,551)$ and attempting to flee the lascivious and cruel Spaniard (Figure 21). The latter is a subtle manipulation of the Andean right/male, left/ female coordination, for conflict and disorder are registered only from the indigenous perspective. The sex signs are reversed only within the Indian group 
"SEGVYDAEDADDEIV

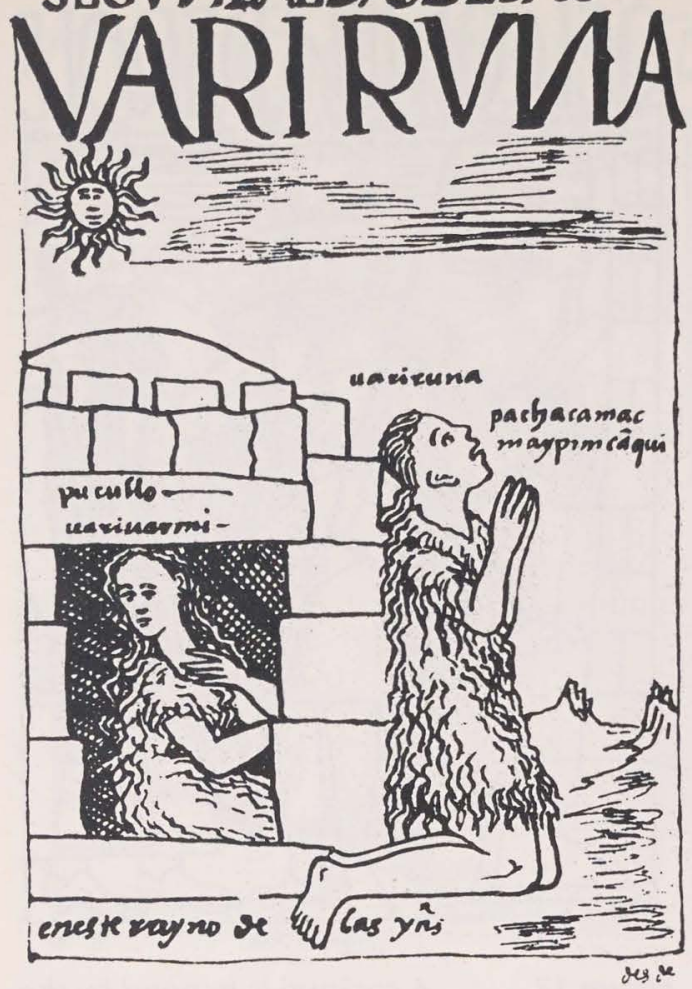

Figure 18 -The early Indians seek their creator (1936:53).

FIESTASDELOS AVDISVIOS CALCAAVAMMACA

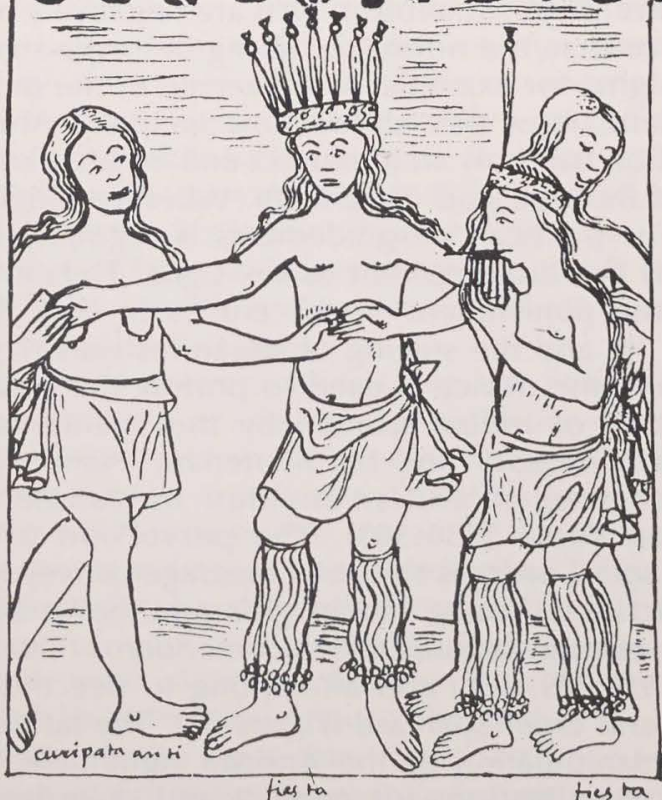

Figure 20 - The festival rites of the Ande Suyo, described as pagan by Guamán Poma (1936:322).
VIUPILALICASTIGO

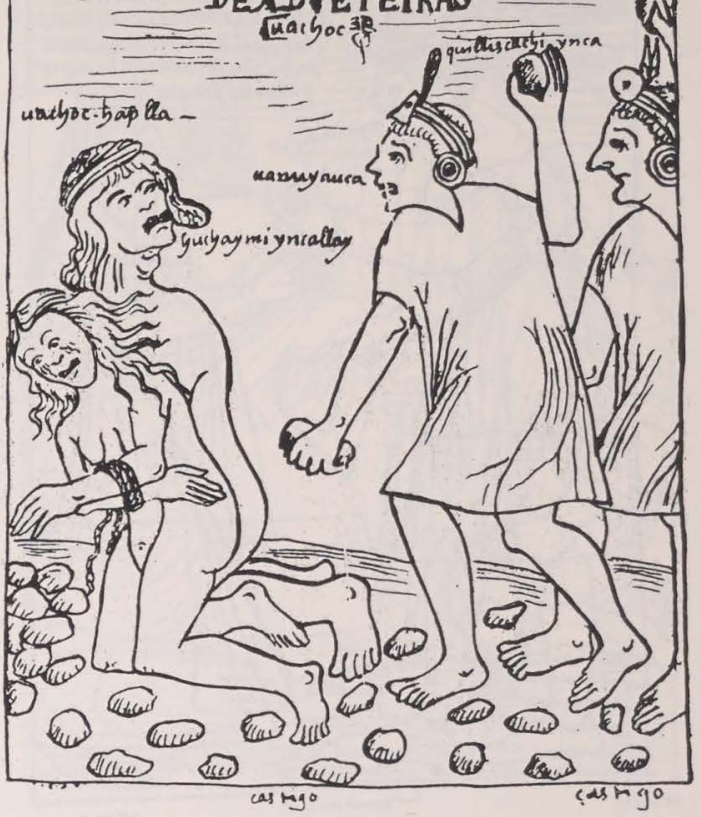

Figure $19-A$ couple is executed for adultery by the Incas' executioner (1936:306)

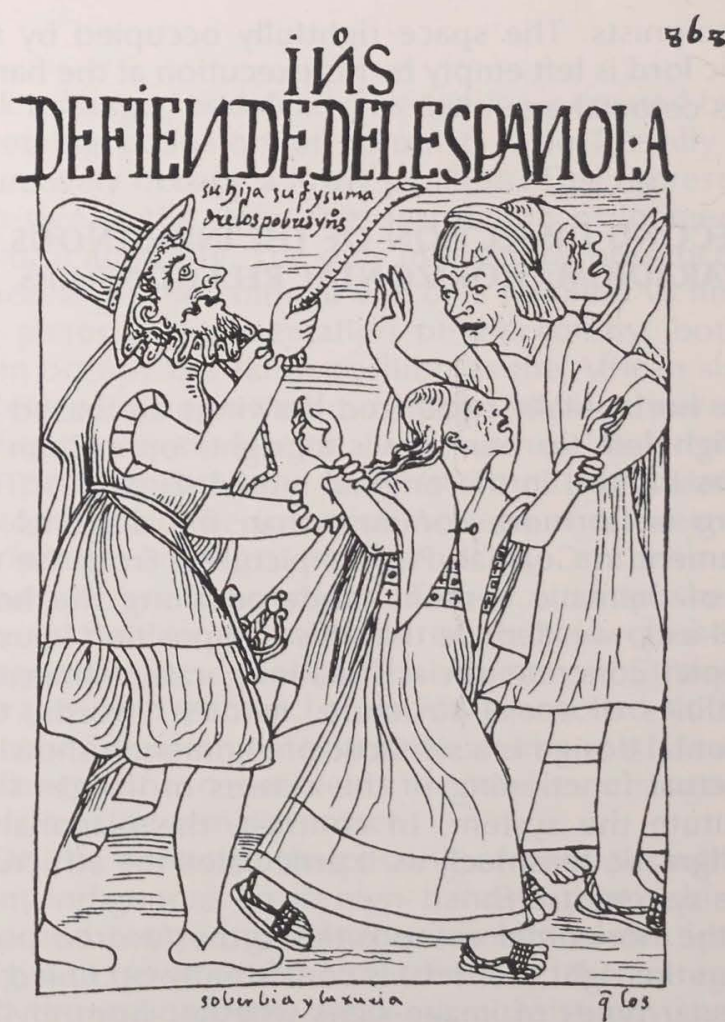

Figure 21 -An Indian couple defend its daughter from the lascivious Spaniard (1936:868). 
itself but not for the whole composition; the figure at the extreme right (our left) is the Spanish male.

In addition to the male/female principle, the oppositions master/servant and righteousness/villainy are sometimes displaced from the normal right/left order. There again, an auxiliary sign conveys the message typically carried by the right/left distinction. One example is the scene in which an Inca prince is slain by a traitorous captain (Figure 22). The latter has usurped the right-hand position of privilege. To register the violation of rightful order, the artist hangs the victim prince head down.

When Indian and Spaniard come together on the horizontal axis, the first and third oppositions of godly/human and master/servant converge into a single contrast. The Indian's image is one of righteous, disenfranchised proprietor; the Spaniard is the villainous alien and usurper. Thus, the Andean figure occupies the position of superiority on the right (our left). This design is repeated in drawings that begin with the Spaniards' arrival and reception by the natives at Tumbes and continues through contemporary scenes like that of a cacique being robbed by a wicked Spanish judge (Guamán Poma 1936:375, 529). In Guamán Poma's views of the colony, the Indian is typically on the right, the Spaniard on the left.

There are only a few exceptions to this practice, and these pictures trace the development of colonial Spanish-Indian relations. The first of them visually supports Guamán Poma's contention that the Inca nobility initially accepted the foreign invaders and cooperated with the early colonial authority. The graphic demonstration consists of Inca princes shown seated in amiable conversation with a Spanish captain and a Spanish viceroy respectively; the foreigners are placed in the right-hand position of honor (Guamán Poma 1936:440, 460).

The pattern established above is quickly reversed to the original ordering as incipient social harmony breaks down, and the Indian is portrayed as wronged authority and innocent victim. The notion of the Indians' innocent suffering is corroborated by the images of Christian sacrifice. In religious drawings of the horizontally elaborated series, the symbols of Christian martyrdom are regularly placed on the right-hand side. These strengthen, by analogy, the image of the Indian as a figure of righteousness and innocence. On the few occasions when the Spaniard usurps the privileged position, the pejorative sign of leftward directional orientation again intervenes to negatively value the scene (Guamán Poma 1936:519, 796).

In addition to general directedness, the placement of the head of a prone, horizontal figure denotes a favorable or unfavorable interpretation of particular scenes. Thus, the head of a life-size statue of Christ on a crucifix is placed, predictably, at the right of the tableau (Guamán Poma 1936: 673). Similarly, the figures of Inca captains being slain during the Conquest by miraculous visions of St. James or by the Spanish benefactor of the author's family fall prone with their heads oriented to the right (viewer's left) (Figure 23;
Guamán Poma 1936:392). However, the Spaniards' executions of the Inca princes Atagualpa Inca and Topa Inca, as well as numerous attacks on defenseless Indians, are regularly oriented the opposite way. The victims' heads are posed leftward (rightward, in our view) as a sign of condemnation of the deed (Figures 24 and 25; Guamán Poma 1936:451, 538, 540, 594).

\section{THIRD DISSECTION OF THE INDIGENOUS MODEL: THE SECONDARY DIAGONAL AS PRIMARY DIAGONAL REVERSED}

The third major compositional pattern is the opposite or mirror reflection of the primary diagonal design. Consisting of a diagonal directed from lower right to upper left (our lower left to upper right), this line duplicates the second division of space in the Andean model (Figure 1). The principle that defines the majority of the drawings organized along this axis is the contradiction of the structure of hierarchy implicit in the primary diagonal. In effect, this diagonal represents the perversion of the order there established, with the result that the structures originally conceived are transformed in the following way:

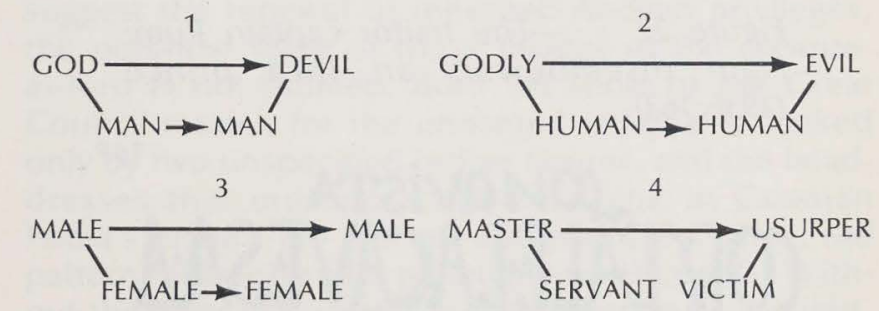

Although several of the examples to be given here may seem to pertain to the field of actual social relations, this is not the horizontal axis of syntagmatic signification that depicts such specific moments. We previously defined the primary diagonal axis as the representation of the system, as the articulation of spiritual and social structures. The secondary, or reversed, diagonal is also paradigmatic in character. As in the former case, verticality stands for hierarchal authority. The reintroduction of the category god/ man in this compositional pattern identifies this second diagonal as the marker of systematic structure. As the opposite or mirror image of the primary diagonal, this one represents structures which have been perverted or altered in ways negatively valued. Traced along this line are the Inca substitution of idolatry for the Judeo-Christian religious tradition and the colonial subversion of the autochthonous organization of Andean society.

As the diagonal swings around to point leftward, the image of the devil replaces that of god. While Old Testament heroes and Christianized Indians look up and to their right to find their creator, the practitioners of pagan Inca rites and cult practices are accom- 
${ }^{263}$ ELOИ 3 E CAPITAИ RVMILAVI TRADDR = OM

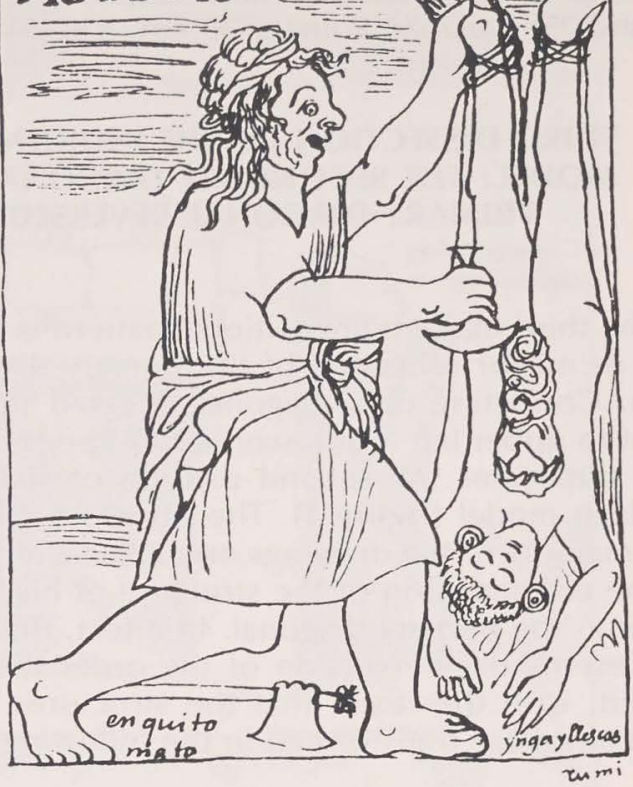

Figure 22 -The traitor captain Rumi Naui disembowels an Inca prince (1936:163).

conavista

CORTALELACAVESAA ATAGVALATIMGA.VMATACVCHY

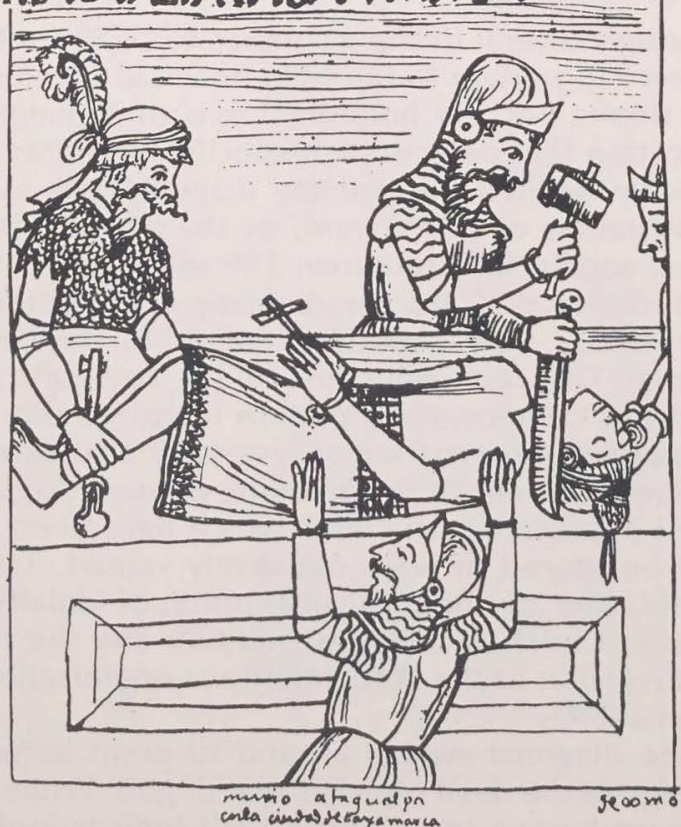

Figure 24 -The conquistadores execute the Inca prince Atagualpa (1936:390). conavista
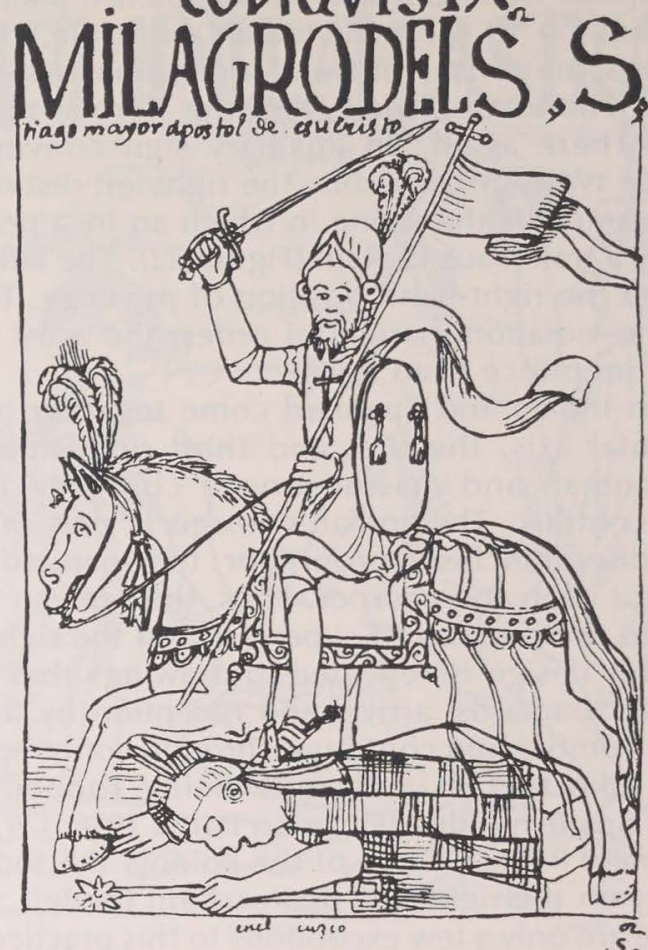

Figure 23 -The miraculous vision of St. James bests an Inca captain during the Conquest (1936:404).

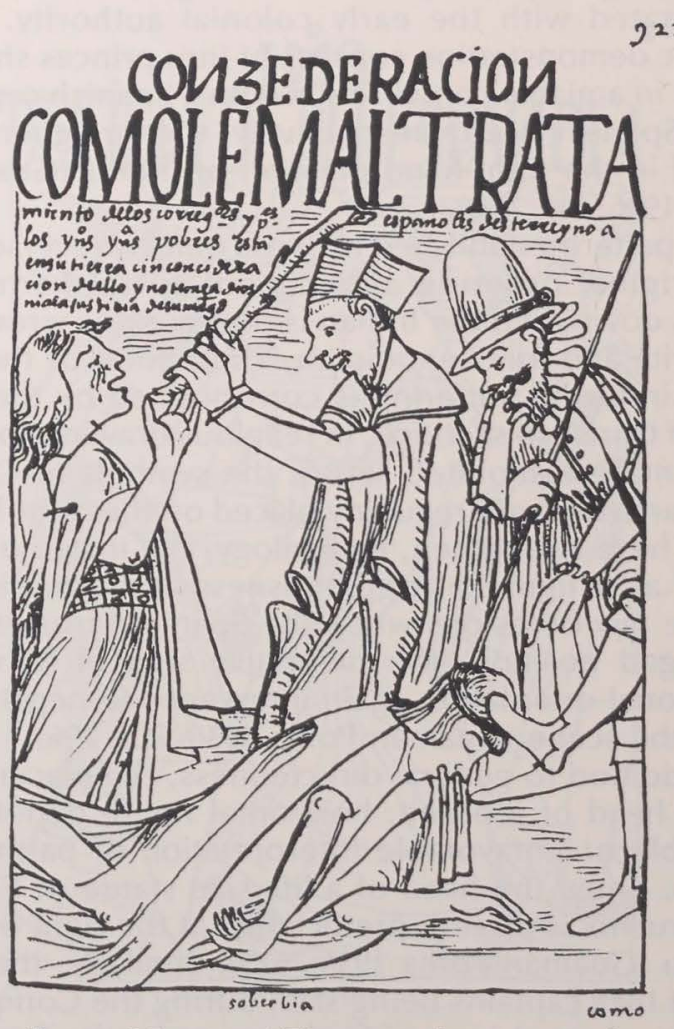

Figure $25 \quad$ - "The way the corregidores and priests mistreat the Indians" (1936:922). 
panied by the image of the devil at their upper left (our upper right). This practice holds for the representation of both ancient and modern times (Figures 26 and 27). The leftward orientation of Guamán Poma's picture of a giant mouth of hell corroborates the fixity of the conceptual left as the domain of evil (Figure 28).

The dark forces of evil hold sway in general over the region of the upper left as godliness is perverted into man's wickedness. That portion of the field is regularly occupied by murderers, corrupt corregidores, vagabond ruffians, and lascivious and wicked priests. In most cases, these figures are juxtaposed with their Indian victims who occupy the position on the lower right. The right-hand feature equals the Andean ideal of superiority (merely moral here), and the aspect of lower stands for subjugation and defeat. Likewise, the reversal of the members of one opposition is often coordinated with that of others to intensify the negative interpretation of the scene. In "The Way the Corregidores and Priests Mistreat the Indians," the transformations of the pairs male/female, godly/ human, and master/servant into those of female/male, human/evil, and victim/usurper respectively, converge into a single sign of social chaos (see Figure 25).

\section{FOURTH DISSECTION OF THE INDIGENOUS PARADIGM: THE PRESENCE OF A MEDIATING CENTER}

As shown above, the various diagonal and horizontal compositions generally consist of two figures that act as the members of an opposition. Very few drawings incorporate the privileged center which was the seat of the Inca and his imperial capital in the pre-Hispanic model. It remains to examine those few cases where a center is present to mediate the terms of opposition.

Among the many drawings deployed along the primary diagonal, only one has its midpoint or central position explicitly marked. That picture represents the coming of a new order: the arrival of the Christian gospel to pagan Peru. The actual scene is the visit of St. Bartholomew to the site of the Cross of Carabuco (Figure 29). While the saint stands at the upper right (our left), and the Indian convert kneels in wonderment below, the center is filled by the cross which bears the marks of the stakes used to crucify Christ. This nucleus sends a mixed message. On one hand, the Christian gospel mediates and joins the New World with Western civilization, bringing the promise of spiritual salvation. At the same time, the detail of the stake serves as a reminder that the cross is a symbol of martyrdom. Three marks on the cross anticipate the Indians' suffering and sacrifice at the hands of the foreign invaders.

While the cross serves as a prominent centering device in the Carabuco drawing, it appears as a leitmotif in several other diagonally arranged pictures. In such instances, the appearance of a tiny crucifix, usually on a rosary, creates the hint of a pictorial focal point at the center (Guamán Poma 1936:635, 821, 823, 833). It would seem that Catholicism is thus offered as the possible mediator between the Old World and the New. Nevertheless, it is necessary to examine other Christian symbolism in different compositional types to determine the efficacy of Christianity as a centering device.

The drawings of horizontal design incorporate articulated centers with greater frequency. Such compositions reflect the center of the original model as it is flanked by sectors I and II (Figure 1). As a simplification also of the formal arrangement in Guamán Poma's Great Council of the Inca (Figure 7), pictures following this pattern have a paradigmatic quality. That is, they represent the structure of human institutions and experience. One of these special drawings is explicitly a variation of the Great Council tableau in which the author Guamán Poma addresses his people (Figure 30). Since it appears immediately after the Great Council picture in the original text, the notion of the "prince's" succession to the Inca's place is implicit. In another drawing a cacique, similarly dressed in the courtier's costume, petitions the colonial authorities on behalf of his humble subjects (Figure 31).

While both of the drawings noted above might suggest the renewal of inherited Andean privileges, the potential force of these images of the caciqueas-lord is not fulfilled. Both fall short of the Great Council model, for the unnamed cacique is flanked only by two unspecified Indian figures, and the headdresses that indicate traditional rank in Guamán Poma's picture are blurred and confused. Thus, the pattern lacks essential paradigmatic elements. Without the parts, the center cannot function as it ought. The symbolism of the central position of the cacique-as-lord is structurally debilitated by the absence of an articulated periphery.

All the remaining three-member, horizontal compositions follow religious themes. The pictorial center is occupied by figures such as the Virgin, saints, and officers of the church. Among these horizontally organized religious pictures, only one image-sign is repeated: the figure of an Indian baby being baptized (Figure 32 ). Through this symbol, the signs of the indigenous race and the foreign religious ideology are superimposed as they were in the figure of the mestizo priest (Figure 8 ). Here, however, native society and the Catholic church decidedly converge, for the image occupies the central, rather than the peripheral, position. With the addition of the images of infant baptism, the figure of the Indian occupies the center of the horizontal composition in two different contexts (cf. Figure 32 with Figures 30 and 31). This figure is another candidate for Guamán Poma's designation as the mediator between native and colonial society.

There are two final variations of the tripartite compositions which feature a center. These are triangular compositions which, right-side-up or inverted, par- 


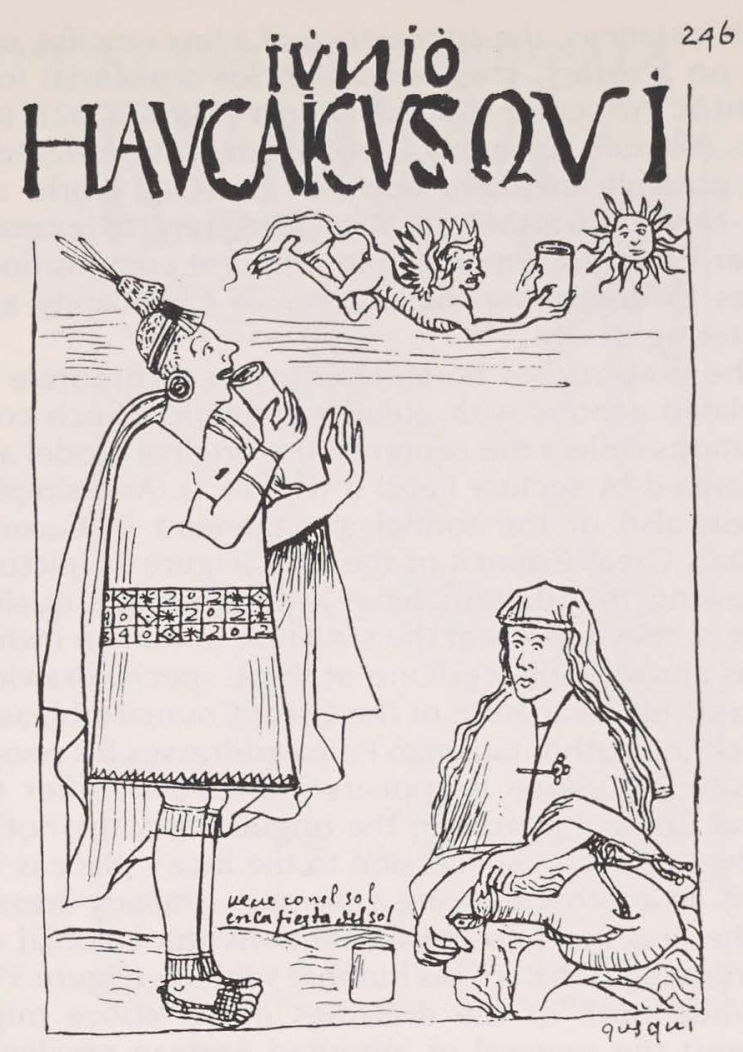

Figure $26 \quad-$ "The Inca drinks to the sun during the festival of the sun" (1936:246).

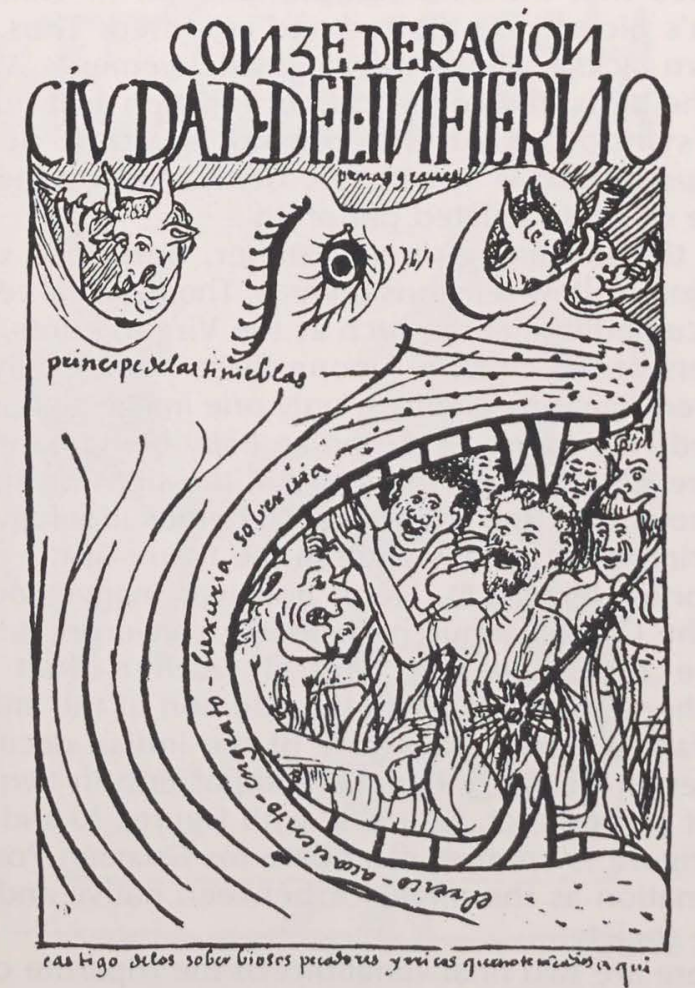

Figure $28 \quad-$ The mouth of a ferocious monster: the City of Hell (1936:941).
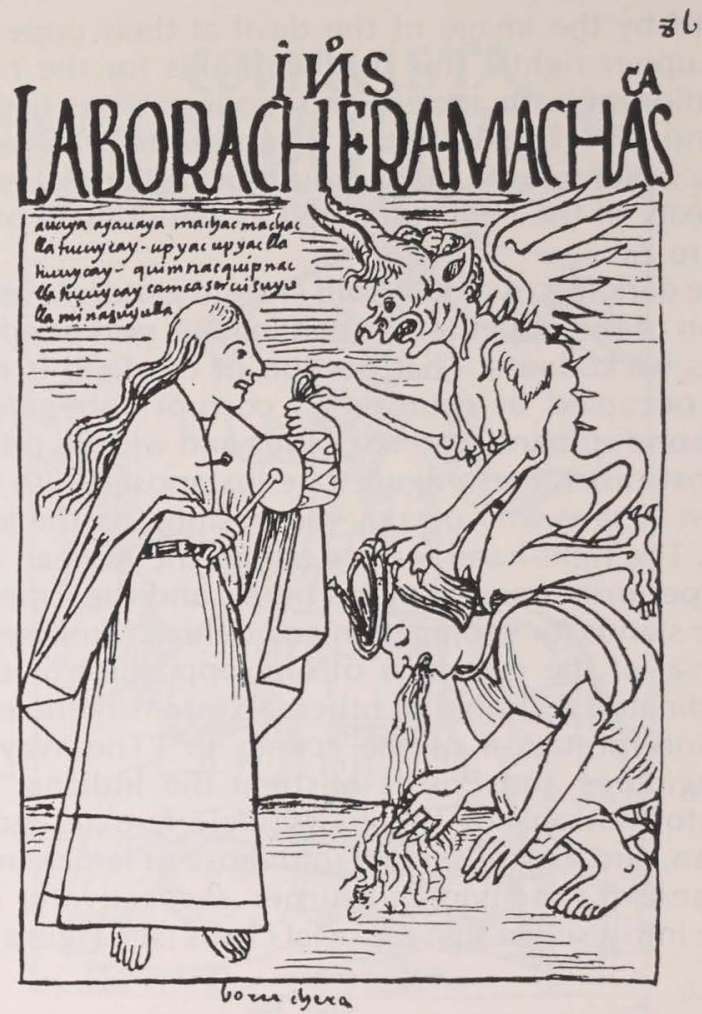

Figure 27 -The devil presides over the drunken dancing of taki unquy, the dancing sickness (1936:862).

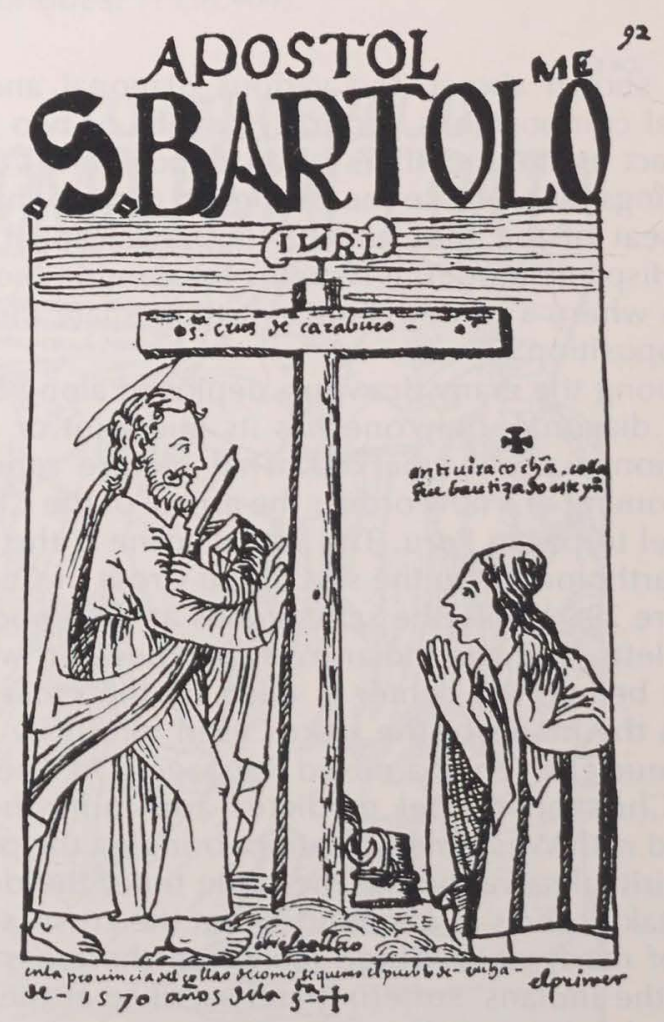

Figure 29 -The Cross of Carabuco: St. Bartholomew brings the Christian gospel to the Indies centuries before the arrival of the Spaniards (1936:92). 
^PREGVYTAELLAVTOR MAVILAALALHMMTAMA

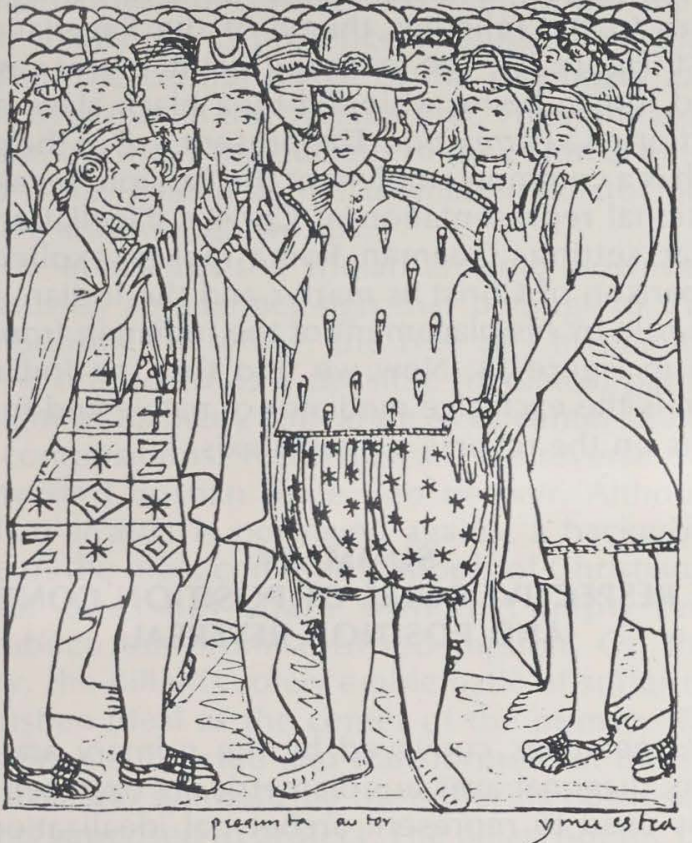

Figure 30 -Guamán Poma consults with his people (1936:366).

$6 \times 3$

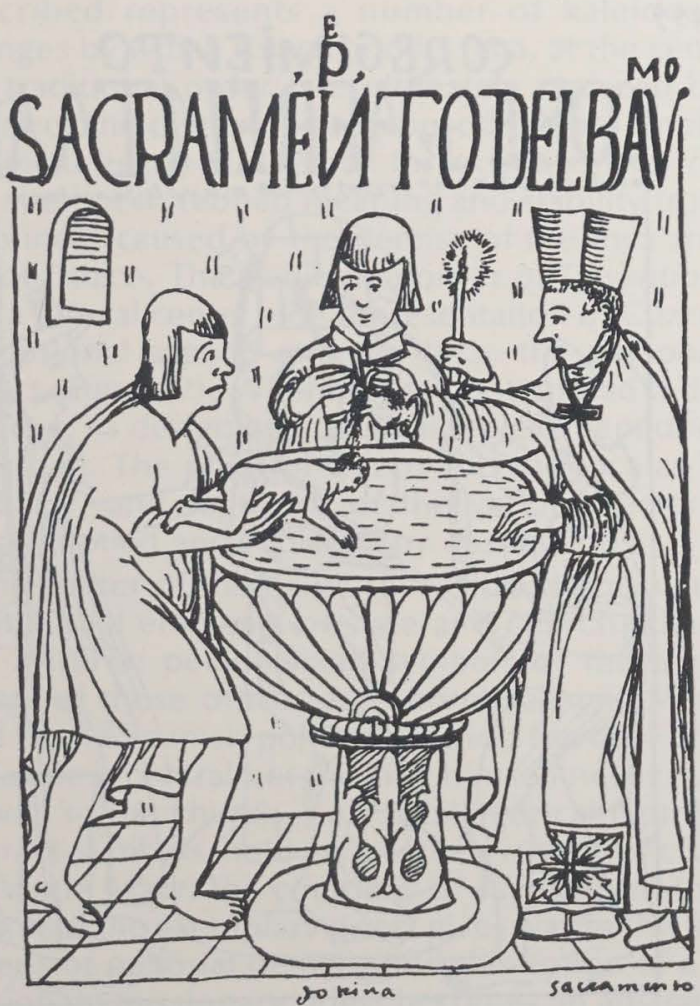

Figure 32 -The baptism of the Indian infant (1936:613).

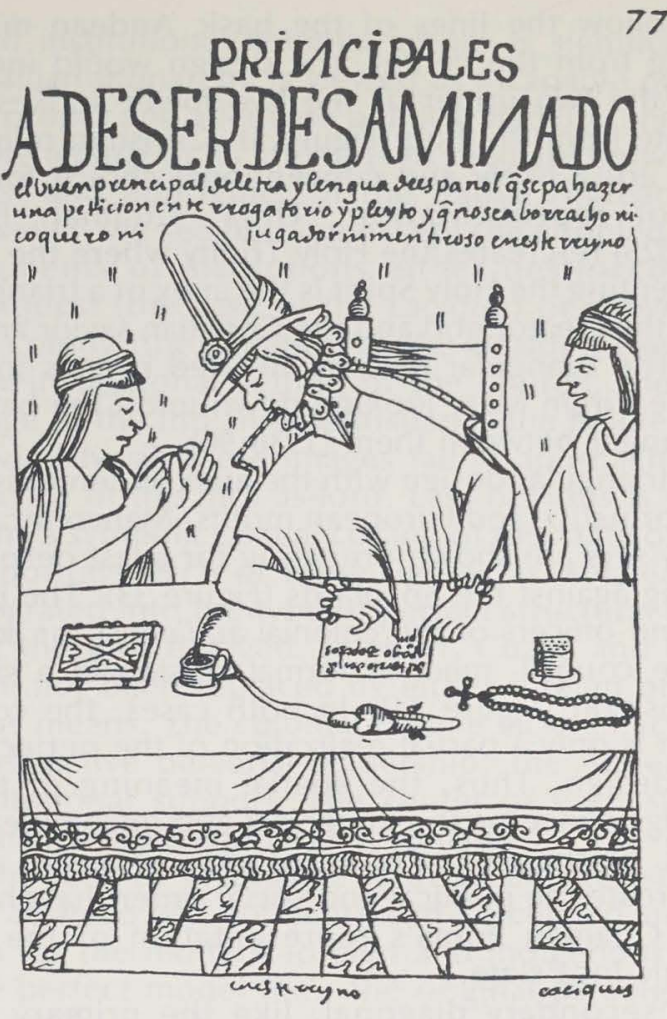

Figure 31 - The good cacique represents his people through the petition process (1936:770).

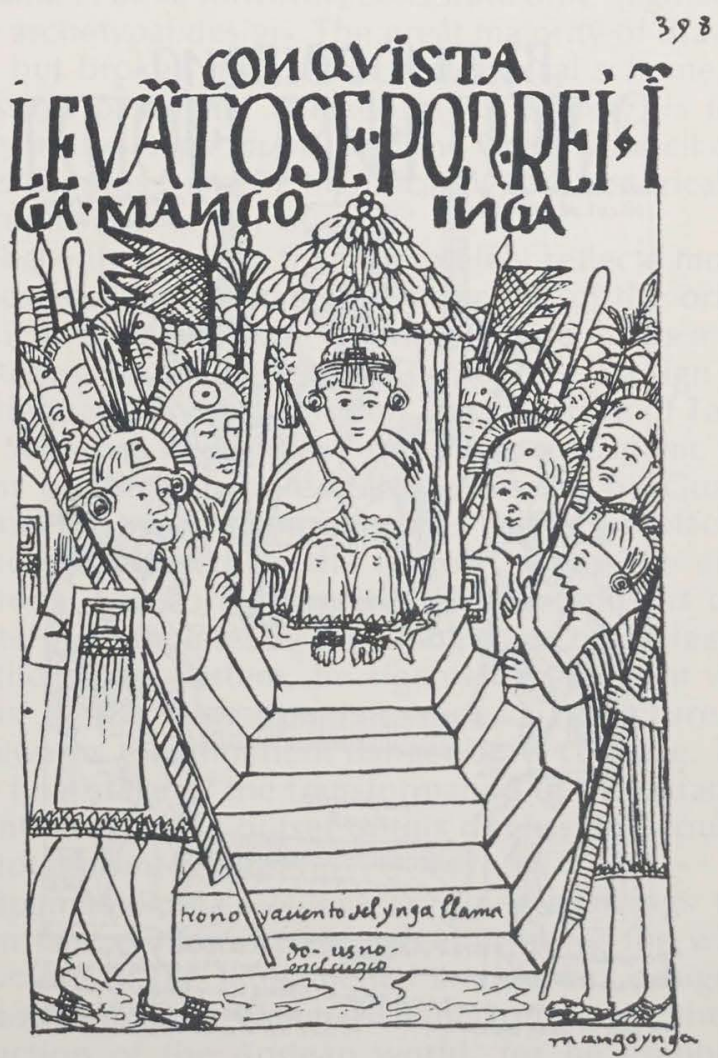

Figure 33 - The prince Manco Inca prepares his rebellion against the Spaniards (1936:398). 
tially follow the lines of the basic Andean model. Starting from the center, the design would include either the two upper or the two lower spokes that emanate from the hub (Figure 1). Christian religious motifs are a likely and conventional choice for this type of representation. Thus, Guamán Poma (1936:825) re-creates the Holy Trinity where the dove representing the Holy Spirit is the apex of a triangle of which the creator god and the Christian savior are the base. The triangular pattern inverted reveals Joseph and the Virgin Mary looking down upon the baby in the manger between them (1936:90).

The triangular design with the apex as center is also used for native and European motifs. Manco Inca and his advisers are shown preparing for a last desperate uprising against the Spaniards (Figure 33 ). The president and officers of the colonial audiencia, or administrative council, meet in formal session in a similar composition (Figure 34). In both cases, the configuration is only a partial realization of the perfect Andean design. Thus, the spatial meaning of these drawings concerns the imperfect and imcomplete attempts, on the part of Andeans and Europeans alike, to re-create the political and social order that characterize Guamán Poma's representation of the preHispanic Inca state.

The secondary diagonal, like the primary one, boasts only a single drawing that features the central position, and in it, too, the Andean design is only partially realized. The cross of Carabuco, the symbol of Andean Catholicism, comes to occupy the mediating center between Andean and Western worlds, but the center of the reverse diagonal is filled with a negatively valued image. The drawing in question features an Indian alcalde, or civil officer, and alludes to the religious theme of the flagellation of Christ (Figure 35). The martyred victim in this case is a naked Indian being whipped by a black slave at the direction of a corregidor. The present use of the pillar, which is a common emblem of the Passion, recalls the traditional representation of Christ's flagellation in a similar setting. Guamán Poma makes explicit the comparison of Christ as martyr and the Indian in the same role by his placement of the Indian in front of a cross in Figure 14. Now we find that the Indian-asvictim is the exclusive mediator of native and foreign realms on the reverse diagonal axis.

\section{SUMMARY: \\ THE RESPECTIVE ROLES OF POSITION CONTENT AND POSITION REVERSAL}

The meanings conveyed by the primary and secondary diagonal axes are diametrically opposed. The first is used to represent archetypal idealizations of spiritual, social, and political structures. The second

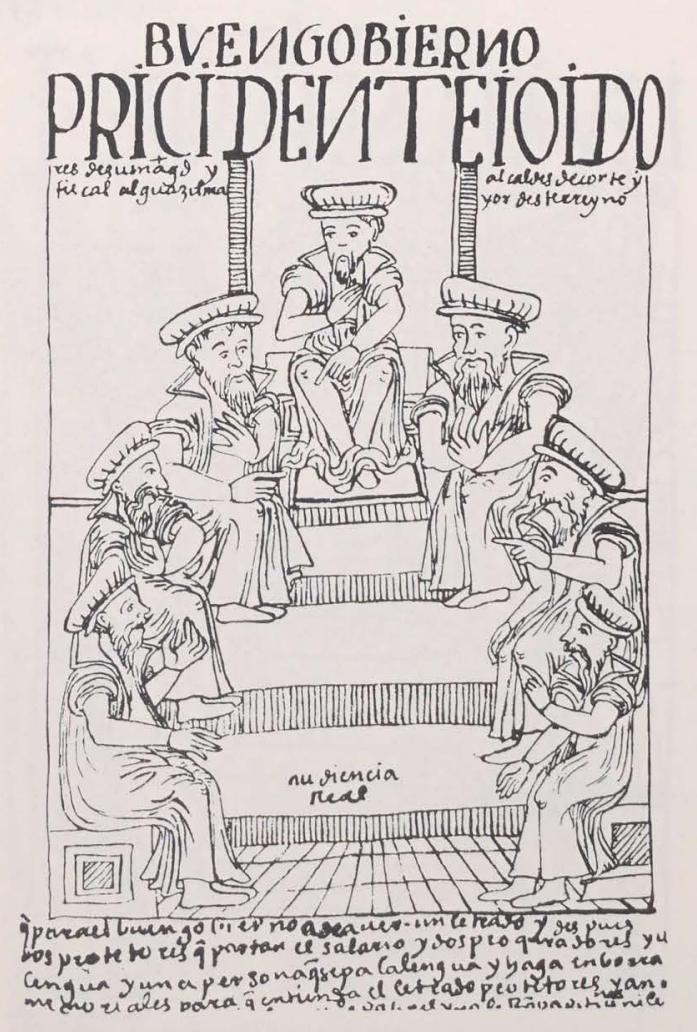

Figure $34 \quad$-The president and officers of the audiencia real meet in formal session (1936:484).
499

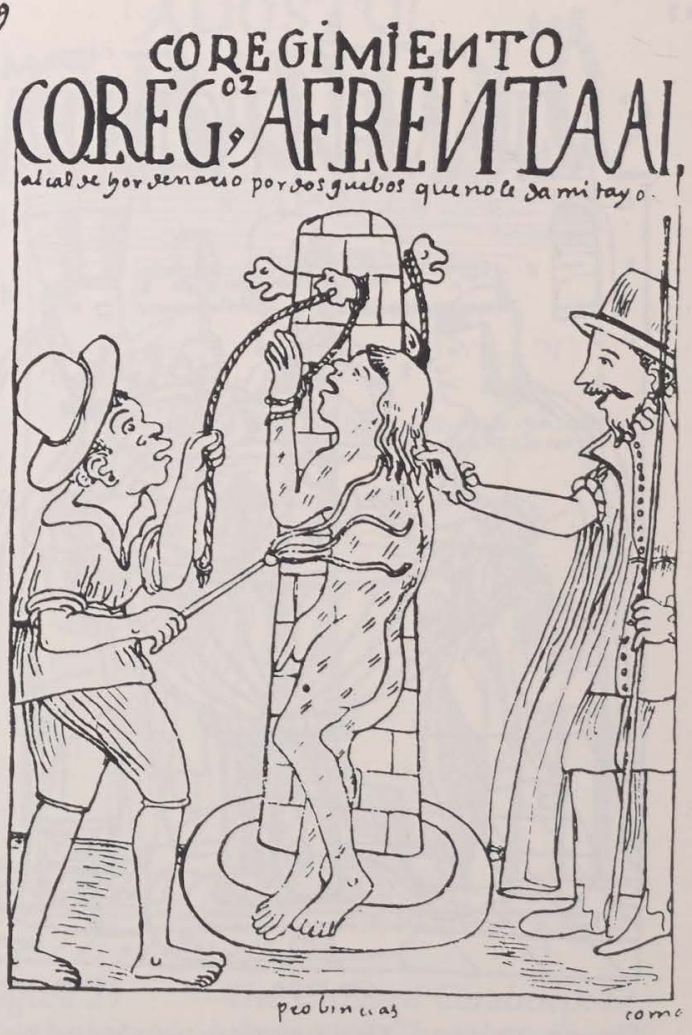

Figure 35 -The corregidor and his slave beat an Indian alcalde (1936:499). 
offers a definitively negative view of social structures and cultural patterns. At the center of these diagonals, there are only two figures: the abstract sign of the cross on the primary one and the personalized sign of the beaten Indian on the secondary axis. As the personal aspect is needed to empower the center with vitality (cf. its presence and absence in Figures 2 and 6 ), the central image of the secondary axis prevails over that of the primary one. Thus, the exploited Indian becomes the nucleus of the colonial enterprise and is designated as the ultimate mediator between native and foreign worlds.

The attack on the Indian alcalde, however, also possesses an abstract sign that belongs to Christian symbolism. Therefore, the role of Christianity must be reconsidered as a possible mediator, particularly in light of its many appearances as center in horizontal compositions. Nevertheless, the reverse diagonal converts Christian hope into despair. Although the Indian alcalde is portrayed against a background of one of the most common symbols of Christianity, the pillar does not share with the empty cross of Carabuco the promise of redemption. On the contrary, the pillar is solely emblematic of suffering. The Christian ideal as the center of the primary diagonal has been subverted and transformed on the secondary axis into symbolizing the suffering of those whom it was supposed to protect. The pillar, not the cross, is the abstract aspect of the pictorial mediation of the Spanish/Andean colonial hierarchy.

All in all, the pictorial transformation this paper has described represents a number of kaleidoscopic changes by which Cuzco and its Inca, at the center of the traditional order, are ultimately replaced by the figure of the degraded and abused Indian; implicitly, the pictures tell of a search for a center. They record the attempt to rebuild meaning and stability from the emptiness caused by the demise of the Inca and the fall of Cuzco. The traditional order of Tawantin Suyo had a bifocal center; the representation of Cuzco, the institutional aspect, and the Inca, the personalized aspect (Figure 2). Whereas that system had a double nucleus, its designated political replacement does not (Figure 6). The place of Cuzco and the Inca as head, mediator, and regulator of the various sectors has been emptied and replaced by abstractions.

The center of the new order is filled only with the institutional emblems of state and church (Figures 7 and 29). The personalized symbols of the administrators of those offices are entirely absent. With regard to the Spanish political empire, the coat of arms of Castile is central but the king himself never is. With respect to the church, only its allegorical figures and abstract symbols hold sway: the cross, the crucifix, the Virgin Mary, the company of saints. Even the depiction of the exemplary priest gives way in the face of dozens of pictorial denials, and the notion of a compassionate missionary priest becomes an abstraction.

The absence of the signs of personal intervention in both institutional colonial arenas is significant. The Castilian monarchy is viewed as incapable of providing proper and adequate political stability; the church is ineffectual in its attempts to mediate between colonist and aborigine. In the native Andean realm, however, we see nothing except the crippled, human fragments of institutions either destroyed by the Conquest (the case of the cacique) or subverted by the colony (the situation of the alcalde). Even in the new institutional setting of the church, the central image of the Indian-as-Christian is the helpless baby. Obviously, all these images fail to approach the old potency of the Inca-as-lord. Less obvious is Guamán Poma's symbolic spatial coding of this state of affairs: he portrays each of these figures as isolated, never integrated into the type of perfect structural network that the Inca enjoyed. In short, Cuzco and the Inca have not been replaced by either foreign or indigenous means. The colonial regime lacks effective and constructive personal leadership; the Andeans lack institutional support. The center of each sphere is partially empty and lacks resonance.

The lack of resonance is deduced precisely from the absence of a complete and articulated visual system for the modern foreign and indigenous realms. The perfect model (i.e., the original paradigm) consists of four sectors arranged around a center, which was a system both autonomous and complete. The entire range of compositional patterns used by Guamán Poma, however, constitute only fragments of the archetypal design. The great majority of drawings are but broken bits of the prototypical scheme. The classical paradigm, realized in its entirety, is found only in the mapa mundi and the Great Council drawings (Figures 2 and 7). Significantly, the historical Inca occupies the center of each.

The only drawing that completely reflects modern times and approximates the structure of the original design is the title page drawing (Figure 6). Its incompleteness, in the light of the prototype, is a sign of its inadequacy as a new model. The structure of Tawantin Suyo has been transformed into a Hispanic kingdom of the Peruvian Indies. As seen by Guamán Poma, this new organization has failed to replace the system destroyed by the fall of Cuzco. The artist's pictorial transformation, though ingenious, is deliberately incomplete. By excluding some of the features of the model system, he signals the inherent weakness of the new Spanish imperial structure and forewarns the imminent danger of its collapse. Thus, the final stage of the transformation of the paradigm, mentioned at the outset of this discussion, would be its total disintegration.

Guamán Poma's Nueva corónica drawings tell a grim tale as they exploit part, but never the whole, structure of the fundamental and perfect design. By pictorial means, Guamán Poma reiterates the destruction of the Andean world, for he graphically reenacts the dismantling of its chief symbol. 
${ }^{1}$ Christopher Dilke has recently adapted and translated the Guamán Poma text. Although not as lengthy, the Dilke version is in many ways the equivalent of the popular modern Spanish translation by Bustíos Gálvez. Dilke's work is essentially an English rendering of portions of the Bustios text rather than of the original work by Guamán Poma. (For complete bibliographic information on both modern texts, see under Guamán Poma de Ayala).

${ }^{2}$ The only other indigenous Andean artist and chronicler known to have used visual language is Joan de Santacruz Pachacuti Yamqui. His Relación de antigüedades deste reyno del Pirú (first published in the early 17 th cent.) contains highly abstract, symbolic drawings. Noteworthy among illustrated European chronicles of the period is Fray Martín de Murúa's Historia general del Perú, origen y descendencia de los Incas, which features portraits of the Incas remarkably similar to those of Guamán Poma.

The Andean chronicler's use of pictures, however, far exceeds the limits of Western literary convention. His drawings actually constitute, rather than merely illustrate, the principal text.

${ }^{3}$ The drawings illustrate the classic articles on Inca and Quechua culture in the Handbook of South American Indians (Rowe 1946:183-330; Kubler:331-440) and have been widely featured in numerous scholarly and popular publications to illustrate Andean motifs. The best source of the illustrations is the 1936 Paris facsimile edition of the work, as newer versions contain only a portion of them (Dilke 1978) or greatly reduce their size (Bustios Gálvez 1956 and 1966). The first critical edition, in preparation by John V. Murra and the present author, and to be published by Siglo Veintiuno Editores, Mexico City, will reproduce all the drawings in actual size.

${ }^{4}$ It is not known whether the manuscript ever reached the Spanish court at Madrid. The location of the text from 1615 to 1785 is unknown. At the latter date, the manuscript was cataloged as part of the Old Royal Collection at the Royal Library of Denmark. Brought to international attention in 1908 (Pietschmann 1908), the only known manuscript copy of the text remains in the Copenhagen archives.

${ }^{5}$ The pattern originates in the coordination of the cosmological model of the Temple of Coricancha drawn by Pachacuti Yamqui in his chronicle (Isbell 1976:38-41) and the spatial design of the ancient Andean kingdom (Wachtel 1973:181). According to El Inca Garcilaso de la Vega (1963, vol. 2., p. 28), the attributes of both may be resolved into one fundamental opposition. Thus, Hanan unites the qualities of maleness and superiority with the positions of upper and right; and femaleness and inferiority with the positions of lower and left.

\section{REFERENCES CITED}

\section{Adorno, Rolena}

In press On Pictorial Language and the Typology of Culture in a New World Chronicle. Semiotica.

De la Vega, El Inca Garcilaso

1963 Primera parte de los comentarios reales de los Incas. In Obras completas del Inca Garcilaso de la Vega. Vol. 2. P. Carmelo Sáenz de Santa María, ed. Madrid: Biblioteca de autores españoles.

Guamán Poma de Ayala, Felipe

1936 El primer nueva corónica y buen gobierno. (Facsimile edition published by L'Institut d'Ethnologie, Paris, of the original 1615 work.)

1956 La nueva corónica y buen gobierno, vol. 1. Luis Bustios Gálvez, ed. Lima: Editorial Cultura.
1966 La nueva corónica y buen gobierno, vols. 2 and 3. Luis Bustíos Gálvez, ed. Lima: Imprenta "Gráfica Industrial.'

1978 Letter to a King. A Peruvian Chief's Account of Life Under the Incas and Under Spanish Rule. Christopher Dilke, trans. and ed. New York: Dutton.

Isbell, Billie Jean

1976 La otra mitad esencial: un estudio de complementariedad sexual andina. Estudios andinos 5(1): $37-56$

Kubler, George

1946 The Quechua in the Colonial World. In Handbook of South American Indians. Vol. 2. Julian H. Steward, ed. Washington, DC: Bureau of American Ethnology.

López-Baralt, Mercedes

In press La persistencia de las estructuras simbólicas andinas en los de Guamán Poma de Ayala. Journal of Latin American Lore:

Lotman, J. M.

1975 The Discrete Text and the Iconic Text: Remarks on the Structure of Narrative. New Literary History 6:333-338.

Murra, John V.

1970 Current Research and Prospects in Andean Ethnohistory. Latin American Research Review 5(1):3-36.

1978 La organización económica del estado Inca. México: Siglo Veintiuno.

Murua, Fray Martín de

1962-64 Historia general del Perú, origen y descendencia de los Incas. Madrid: Instituto Gonzalo Fernández de Oviedo.

Ossio, Juan M.

1973 Nueva corónica o carta al rey. Un intento de aproximación a las categorías del pensamiento del mundo andino. In Ideología mesiánica del mundo andino. Juan M. Ossio, ed. Pp. 155-213. Lima: Ignacio Prado Pastor.

Pietschmann, Richard A.

1908 Nueva corónica y buen gobierno des Don Felipe Guamán Poma de Ayala, eine peruanische Bilderhandschrift. Nachrichten von der königlichen Gesellschaft der Wissenschaften zu Göttingen. Philologisch-historische Klasse aus dem Jahre 1908. Pp. 637-659. Berlin: Weidmannsche Buchhandlung.

Rowe, John Howland

1946 Inca Culture at the Time of the Spanish Conquest. In Handbook of South American Indians. Vol. 2. Julian H. Steward, ed. Washington, DC: Bureau of American Ethnology.

Santacruz Pachacuti Yamqui, Joan de

1879 Relación de antigüedades deste reyno del Pirú. In Tres relaciones de antigüedades peruanas. Marcos Jiménez de la Espada, ed. Madrid: Ministerio de Fomento.

Schapiro, Meyer

1969 On Some Problems in the Semiotics of Visual Art: Field and Vehicle in Image-Signs. Semiotica 1:229-234.

Tello, Julio C.

1942 Origen y desarrollo de las civilizaciones prehistoricas andinas. In Actas del $27^{\circ}$ Congreso Internacional de Americanistas. Pp. 589-720. Lima.

Uspensky, B. A.

1975 "Left" and "Right" in Icon Painting. Semiotica 13:33-39.

1976 The Language of Ancient Painting. Dispositio 1(3): 219-246.

Varallanos, José

1946 El Derecho Indiano a través de Nueva crónica y su influencia en la vida social peruana. Lima: Imprenta "El Trabajo."

Wachtel, Nathan

1971 La vision des vaincus. Paris: Gallimard.

1973 Pensamiento salvaje y aculturación. In Sociedad e ideología. Ensayos de historia y antropología andinas. Pp. 165-228. Lima: Instituto de Estudios Peruanos. 